Article

\title{
Indoor Temperature Improvement and Energy-Saving Renovations in Rural Houses of China's Cold Region-A Case Study of Shandong Province
}

\author{
Yanqiu Cui ${ }^{1}$, Ninghan Sun ${ }^{1, * \mathbb{D}}$, Hongbin Cai ${ }^{1}$ and Simeng $\mathrm{Li}^{1,2}$ \\ 1 School of Architecture and Urban Planning, Shandong Jianzhu University, Jinan 250101, China; \\ cyq@sdjzu.edu.cn (Y.C.); arc_yhy101@sdjzu.edu.cn (H.C.); loraloverain@gmail.com (S.L.) \\ 2 School of Architecture and Built Environment, Deakin University, 3220 Geelong, Australia \\ * Correspondence: sunnh2020@gmail.com; Tel.: +86-1835-312-4533
}

Received: 29 January 2020; Accepted: 12 February 2020; Published: 17 February 2020

check for updates

\begin{abstract}
With the continuous implementation of a plan for reconstruction of "Beautiful Countryside" in China, the rural environment and appearance of rural houses have been significantly improved. However, those houses in cold areas of China have great trouble with indoor temperature and heating-related energy consumption. After investigating the current situation of the layout, building envelope, indoor temperature, and energy consumption of the rural houses renovated by the plan of "Beautiful Countryside" in Shandong Province, this paper puts forward the improvement measures of raising indoor temperature and reducing energy consumption. On this basis, a typical rural house was selected, and DesignBuilder was utilized to simulate the effects before and after the application of different renovation measures for this house. The results show that the main way to raise indoor temperature and reduce energy consumption is to improve the thermal insulation performance of the building envelope, including renovation of the roof, exterior walls, doors and windows, and attached sunspace. In addition, combined with the achievements of "Beautiful Countryside" reconstruction, this paper shall propose specific renovation practices which are suitable for different rural houses. Based on the level of economic development in rural areas, it also puts forward some feasible renovation paths for different rural areas, and further provides references for other areas to carry out relevant work in the future.
\end{abstract}

Keywords: rural house; energy consumption; thermal environment

\section{Introduction}

At present, more than 560 million people still live in China's rural areas [1], and the total construction area of rural houses is about 24 billion $\mathrm{m}^{2}$ [2]. Even if China maintains a stable urbanization rate, the number of rural residents and rural houses shall not decline significantly in the short term. By 2030, it is estimated that about 0.5 billion people would live in China's rural areas, and the construction area of rural houses would be about 22 billion $\mathrm{m}^{2}$, accounting for $29 \%$ of the total construction area in the whole country [3]. A large number of rural houses and unreasonable design and construction modes would lead to the large amount of energy consumption in rural residential buildings [4-8]. According to statistics, the energy consumption per unit area in rural residential houses increased from $60.9 \mathrm{~kW} \cdot \mathrm{h} / \mathrm{m}^{2}$ in 2000 to $147.1 \mathrm{~kW} \cdot \mathrm{h} / \mathrm{m}^{2}$ in 2017 [9], with an average annual growth rate of about $5.3 \%$. Simultaneously, many scholars have found that, in winter, low indoor temperature is still prevalent in rural houses of colder northern China [10-12]. In recent years, with the development of society and economy, the rural residents' requirements for living comfort have been constantly improved [12-14]. If there is no control, the energy consumption in rural residential buildings will 
continue to increase in the future. Therefore, how to reduce building energy consumption while raising the indoor temperature of rural houses in winter has become a vital issue to be solved urgently in China's rural areas.

In recent years, the Chinese government has proposed the "Beautiful Countryside" renewal plan, which focuses on the rural environment and the appearance of rural houses [15]. Under the guidance of the plan, the residential appearance in colder northern China has greatly changed, however, the indoor temperature in winter has not been improved, and the building energy consumption has not been reduced. Therefore, even after the renovation of "Beautiful Countryside", the problems of poor living comfort and high energy consumption may still be common in rural houses of this region. In the past, based on the field research of rural houses, some scholars proposed some techniques to improve the residential environment and reduce building energy consumption from the perspective of design theories. He proposed that energy saving in houses and environmental improvement technologies should be established according to rural conditions and characteristics [16]. When a building is designed, the shape coefficient refers to the ratio between its external surface and the total constructed volume. The smaller the shape coefficient is, the smaller the heat dissipation area shared by the unit building space, which causes less energy consumption [17]. Zhao pointed out that the shape coefficient of rural houses shall have a certain influence on building energy consumption and indoor thermal environment, and the shape coefficient should be minimized [18]. Ling and Yan both believed that the relative effective approach was to improve the building envelope of rural houses, in which raw materials should be obtained locally $[19,20]$. On this basis, Liu insisted that a variety of renewable energy sources, such as solar energy or biomass energy, should also be rationally utilized so as to reduce the use of fossil fuels [21]. Some other scholars proposed improvement strategies for rural houses associated with computer simulation technology. Specifically, Shao took advantage of TRNSYS to simulate the temperature of rural houses in Dalian, and the results showed that the window/wall ratio in the south of rural houses had a great impact on the indoor temperature, so the window/wall ratio in the south should be adjusted if able [22]. Lu also exploited TRNSYS and EnergyPlus to optimize the shape and building envelope design aimed at the rural houses in areas with hot summers and cold winters [23,24]. Hu utilized DeST to explore the influence of different building forms on energy consumption, and it turned out that the shape of rural houses in Beijing should be as simple and compact as possible to ensure the smaller shape coefficient, thereby reducing energy consumption of buildings [25]. Zhang used DesignBuilder to prove that in terms of rural houses of the Kangding area, the heat-transfer coefficient for exterior walls and roofs were in direct proportion to the building's heating energy consumption in winter, and the energy consumption of winter heating could be reduced by decreasing the heat-transfer coefficient of exterior walls and roofs [26]. Chen utilized Ecotect for the purpose of simulating the energy consumption in a rural house with or without passive sunspace, and the results indicated that the heating energy consumption of buildings with sunspace was lower than that without sunspace. Hence, sunspaces should be built [27]. Shao made use of DeST to simulate the energy consumption of rural houses with different exterior walls, proving that the structure of exterior walls has largely influenced the insulation performance of rural houses [28]. However, according to the literature, most of the research objects are rural houses that have no renovations from "Beautiful Countryside". For rural houses renovated under the plan of "Beautiful Countryside", relative research on indoor temperature improvement and energy saving based on their specific appearances are relatively lacking.

Shandong Province belongs to the colder northern area in China. This paper mainly takes the rural houses renovated by "Beautiful Countryside" in Shandong Province as the research object, fully combines the climate characteristics of hot summers and cold winters in this region, and proposes reasonable renovating measures after the field research to understand the current situation of rural houses. On this basis, it applies computer technology to simulate the reconstructive effect of each measure, and deeply analyzes results of simulation. Meanwhile, with consideration of the simulation results, the status of rural houses and rural economic conditions, the paper puts forward specific 
renovation practices and paths, which are suitable for rural houses in this area. This paper also provides some theoretical and technical references and values for the reconstruction work in other areas.

\section{The Current Situation of Rural Houses in Shandong Province}

To fully understand the current situation of existing rural houses in Shandong Province, our research group was divided into subunits to conduct the research on 5 pilot villages with 573 rural houses in Jining city under the plan of "Beautiful Countryside" during the period December 2018-February 2019. The research mainly covered the contents with the layout of rural houses, the present situation of the building envelope, indoor temperature in winter, and situation of heating energy consumption, and further put forward some corresponding targeted measures to renovate.

\subsection{Rural Residential Layout}

The rural houses of this research are all single-story courtyard style, which are composed of courtyards and buildings. The main functions of the buildings should include the living room, bedroom, kitchen, washroom, and storage room, etc. In the renovated process of "Beautiful Countryside", the layout of rural houses was not changed. According to the calculation, the shape coefficient of houses in the research area is between 0.77 and 0.83, as shown in Table 1, which is generally larger [25]. Research has shown that, in the cold areas of the Shandong region, an increase by every 0.01 in the shape coefficient of buildings on the basis of 0.3 , building energy consumption will increase about $2.4 \%-2.8 \%$. As the shape coefficient reduces by each 0.01 , energy consumption will be reduced by $2.3 \%-3 \%$ [17], hence the building energy consumption of rural houses in the research region are generally high.

Table 1. The layout and shape coefficient of rural houses in the research area.

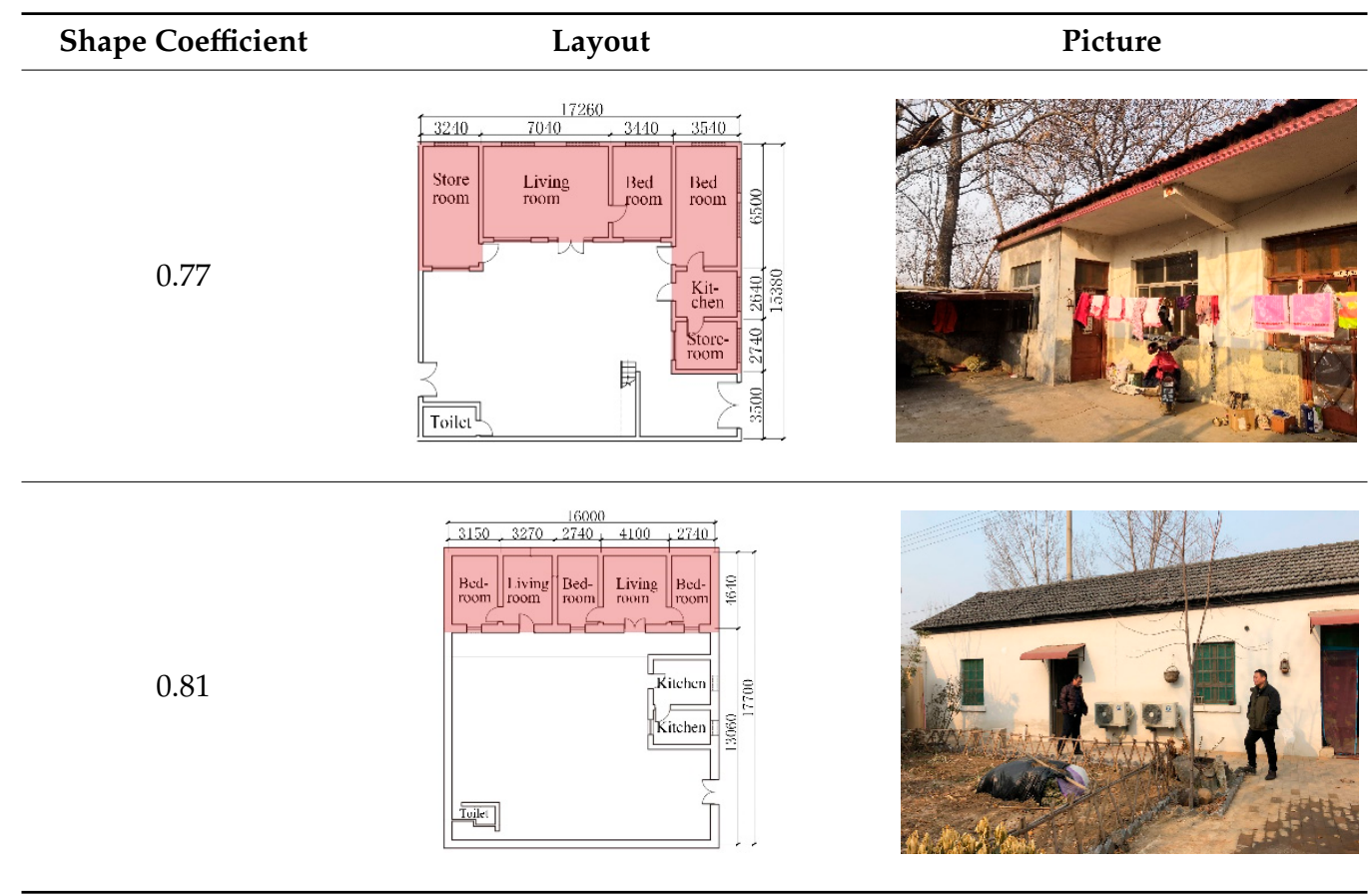


Table 1. Cont.

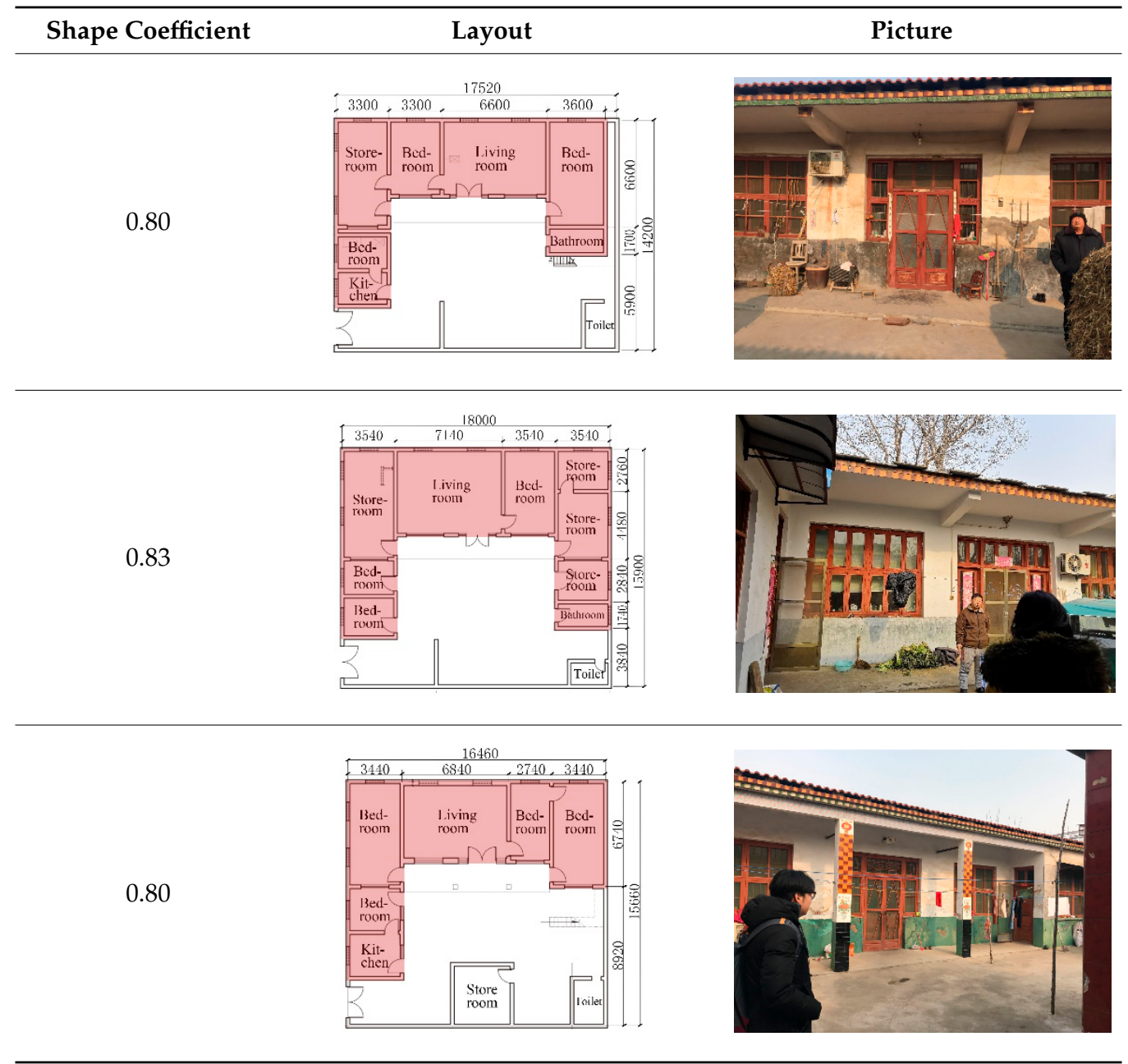

\subsection{Rural Residential Building Envelopes}

The building envelope mainly includes exterior walls, roofs, doors, and windows. According to the field research, the appearance of the exterior walls, roofs, doors, and windows of rural houses have been significantly improved during the reconstruction of "Beautiful Countryside". The reconstructive method of exterior walls will mainly be updated uniformly, of which the common practice is to repaint the exterior wall and design a variety of distinctive regional patterns and characters on the wall. The method to renovate the roofs will additionally build pitched roofs or decorate the parapets and eaves. The method of exterior windows will basically add panes with the traditional style to the outside of the window.

Though the appearance of the building envelope has been promoted, the thermal insulation performance of the building envelope has not been improved during the reconstruction of "Beautiful Countryside". Since the rural houses in the five villages were built in the 1990s or the early 21st century, the exterior walls of local rural houses are not equipped with insulation layers, which are the solid clay brick walls. Figure 1 shows the structural map of the exterior wall. After calculating, the heat-transfer coefficient of the exterior wall is about $2.07 \mathrm{~W} / \mathrm{m}^{2} \cdot \mathrm{K}$ or $1.56 \mathrm{~W} / \mathrm{m}^{2} \cdot \mathrm{K}$, which is far more than the limit value of $0.65 \mathrm{~W} / \mathrm{m}^{2} \cdot \mathrm{K}$ stipulated in the Chinese National Design Standard [29]. The roofs of local rural houses were not laid with insulation layers during construction. Only a small amount of straw or slag was laid to increase the insulation effect of the roof. However, due to the early construction and lack of maintenance, straw and slag have no insulation performance at present. Figure 2 shows the structural map of the roof. After calculating, the heat-transfer coefficient of the roof is about $4.04 \mathrm{~W} / \mathrm{m}^{2} \cdot \mathrm{K}$, which 
is much higher than the prescribed limit value of $0.50 \mathrm{~W} / \mathrm{m}^{2} \cdot \mathrm{K}$ [29]. Doors and windows made of wood or aluminum alloy frame and single glass are commonly utilized in rural houses, as shown in Figure 3 , and the heat-transfer coefficient is $3.8-6.4 \mathrm{~W} / \mathrm{m}^{2} \cdot \mathrm{K}$, far exceeding the prescribed limit value of $2.5-2.8 \mathrm{~W} / \mathrm{m}^{2} \cdot \mathrm{K}[29]$. The excessive heat-transfer coefficient will lead to heat losses through the building envelope, which has a great impact on indoor temperature and energy consumption of the building [26].
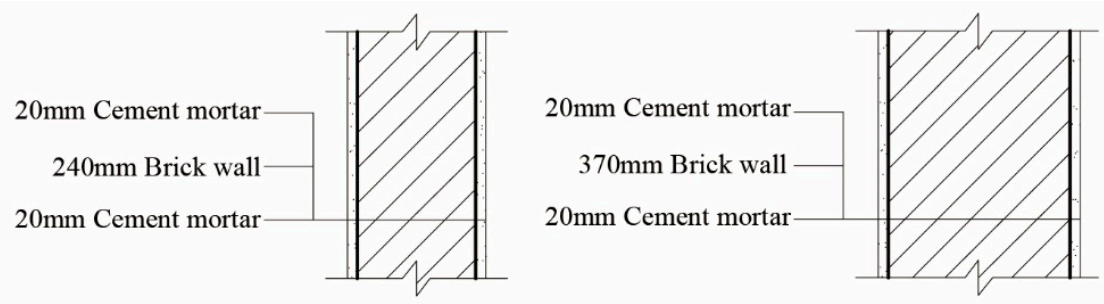

Figure 1. Exterior walls.

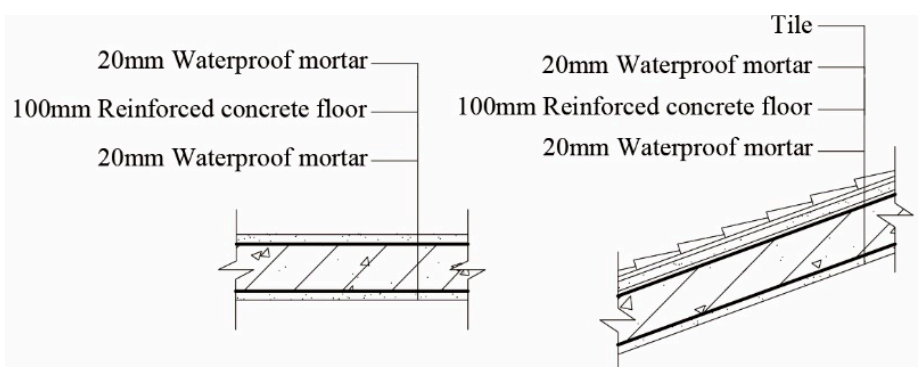

Figure 2. Roofs.
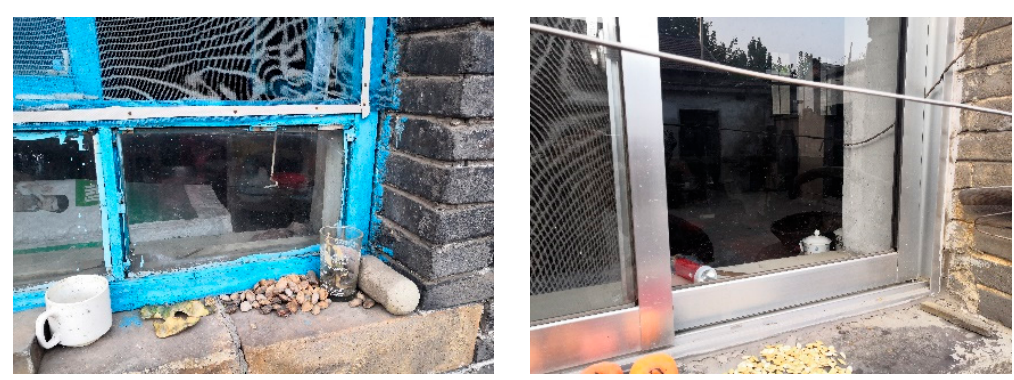

Figure 3. Windows.

\subsection{Rural Residential Indoor Temperature and Heating Energy Consumption in Winter}

Depending on natural ventilation, the rural houses in Shandong Province can get a comfortable indoor temperature in summer, and there is no need to use more energy-consuming air-conditioning or other cold resource equipment. Oppositely, in winter, the lower indoor temperature of the rural houses resulted from the low outdoor temperature, and it is essential to raise the indoor temperature provided by heat-source equipment. Therefore, it is necessary to research the indoor temperature without heating and energy consumption of rural houses with heating in winter, and further put forward some reasonable improvement measures. 
To better understand the indoor temperature of rural houses without heating facilities during the winter, the research selected two typical houses after having been reformed with "Beautiful Countryside": Rural House 1 and Rural House 2. Then it used the Elitech RC -5 temperature recorder (temperature accuracy $\pm 0.5^{\circ} \mathrm{C}$ ) to test indoor and outdoor temperature changes for two rural houses, respectively, at the exact same moment [30]. The indoor measuring points were mainly selected in the living room and master bedroom of the house, and the temperature recorder was placed in the geometric center of the room, which was $1.6 \mathrm{~m}$ above the ground. While the outdoor measuring point was selected in a shady and ventilated place in the farmyard, with a height of $1.6 \mathrm{~m}$. To avoid the influence of solar radiation on the test results, a layer of aluminum foil was wrapped around the temperature recorder, as shown in Figure 4 [31,32]. The temperature in Shandong Province generally reaches the lowest point before and after the Greater Cold (20 January), which is a day marking one of the 24 divisions of the solar year in the traditional Chinese calendar. Thus, the test time was selected for four consecutive days including the day of Greater Cold (18 January-21 January). The temperature data was recorded at an interval of $15 \mathrm{~min}$, and the temperature curve was drawn according to the test results, as shown in Figure 5. According to the analysis of this curve, the lowest outdoor temperature during the test period was about $-5.8{ }^{\circ} \mathrm{C}$, which occurred at about 5:00 a.m. on the third test day. At this moment, the temperature in the living room of Rural House 1 was about $2.2^{\circ} \mathrm{C}$, and the master bedroom was about $2.5^{\circ} \mathrm{C}$. While the living room of Rural House 2 was about $1.4^{\circ} \mathrm{C}$, and the master bedroom was about $1.5^{\circ} \mathrm{C}$. After about $4 \mathrm{~h}$, the temperature of each one in the rural house fell to the lowest temperature. To be more specific, the living room of Rural House 1 was about $1.2^{\circ} \mathrm{C}$, and the master bedroom was about $1.5^{\circ} \mathrm{C}$, while the living room of Rural House 2 was about $0.6^{\circ} \mathrm{C}$, and the master bedroom was about $0.8^{\circ} \mathrm{C}$. On the other hand, the highest outdoor temperature during the same period was about $5.1^{\circ} \mathrm{C}$, which occurred around 1:00 p.m. on the fourth test day. At this moment, the temperature in the living room of Rural House 1 was about $3.8^{\circ} \mathrm{C}$, and the temperature in the master bedroom was about $4.2^{\circ} \mathrm{C}$, whilst the living room of Rural House 2 was about $2.7^{\circ} \mathrm{C}$, and the master bedroom was about $3.8^{\circ} \mathrm{C}$. After about $3 \mathrm{~h}$, the indoor temperature of each room in the rural houses rose to the highest point. At this moment, the living room of Rural House 1 was about $5.6{ }^{\circ} \mathrm{C}$, and the master bedroom was about $5.8^{\circ} \mathrm{C}$, whilst the living room of Rural House 2 was about $5.1^{\circ} \mathrm{C}$, and the master bedroom was about $5.4^{\circ} \mathrm{C}$. In general, the average outdoor temperature was about $-0.7^{\circ} \mathrm{C}$, the average temperature of the living room in Rural House 1 was about $2.9^{\circ} \mathrm{C}$, and the average temperature of the master bedroom was about $3.3^{\circ} \mathrm{C}$. Comparatively, the average temperature of the living room in Rural House 2 was about $2.5^{\circ} \mathrm{C}$, and the average temperature of the master bedroom was about $2.8^{\circ} \mathrm{C}$. Thus, it can be seen that the indoor temperature of rural houses in the research area are generally lower without heating in winter. It is significant to consume massive energies for heating to get a more comfortable indoor temperature.
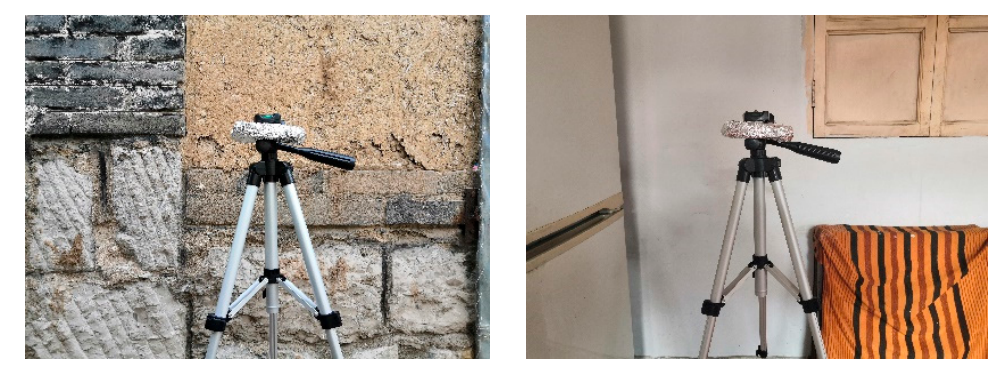

Figure 4. Outdoor and indoor temperature measurement of rural houses. 


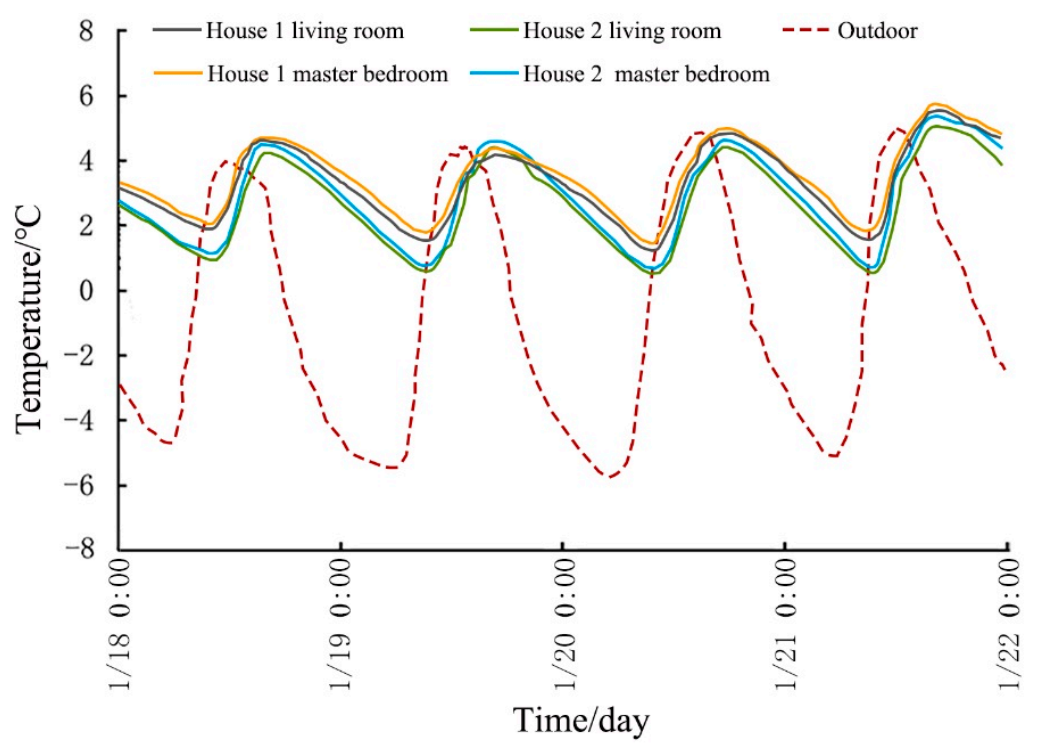

Figure 5. Outdoor and indoor temperature test results of rural houses.

To further understand the usage of energy in winter, 573 households were selected to carry out research on the specific use of energy. It was found that local residents usually use coal for heating in winter. By statistics, in 573 households, there were 384 households consuming coal between 1.5 and 2 tons, 92 households between 1 and 1.5 tons, and 97 households between 2 and 2.5 tons. According to the proportional analyses, as shown in Figure 6, it can be seen that the households that consume more than 1.5 tons of coal account for about $84 \%$ of the total number of households, and the vast majority of rural houses have high levels of heating energy consumption [21].

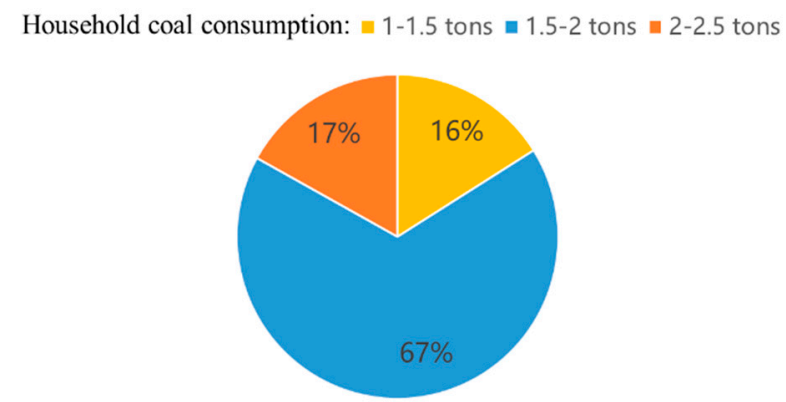

Figure 6. Distribution proportion of household coal consumption.

\subsection{The Optimized Direction of Rural Houses}

On the basis of this research, we can see that the converted farmhouses in the "Beautiful Countryside" transformation have only changed in aesthetics, and have not improved in the physical properties of house construction, yet the indoor temperature of rural houses in winter is still generally low, and the heating energy consumption of houses is still generally large, thus there is need for improvement in terms of indoor comfort and energy saving.

This paper chiefly analyzes the present situation of rural houses; the main reason for larger heating energy consumption and lower indoor temperature in winter due to the building envelope with poor heat preservation. Therefore, in consideration of increasing the indoor temperature of rural houses in winter and reduction of heating energy consumption, the heat-insulating properties of the house's building envelope should be improved. The transformation measure is to build sunspaces for rural houses [27], which is also one of the vital ways to use solar energy in rural houses. It can assist in improving the indoor comfort in winter by increasing the indoor heat gains [33]. Besides, there is need 
to renovate the roofs, external walls, doors, and windows of rural houses, so as to improve the heat preservation of the building envelope [26]. Nevertheless, due to the appearance of rural houses having been transformed completely, attention should be paid to avoid damaging the current appearance in the process of improving the indoor temperature and reducing the heating energy consumption. Figure 7 displays the flow for transforming a rural house.

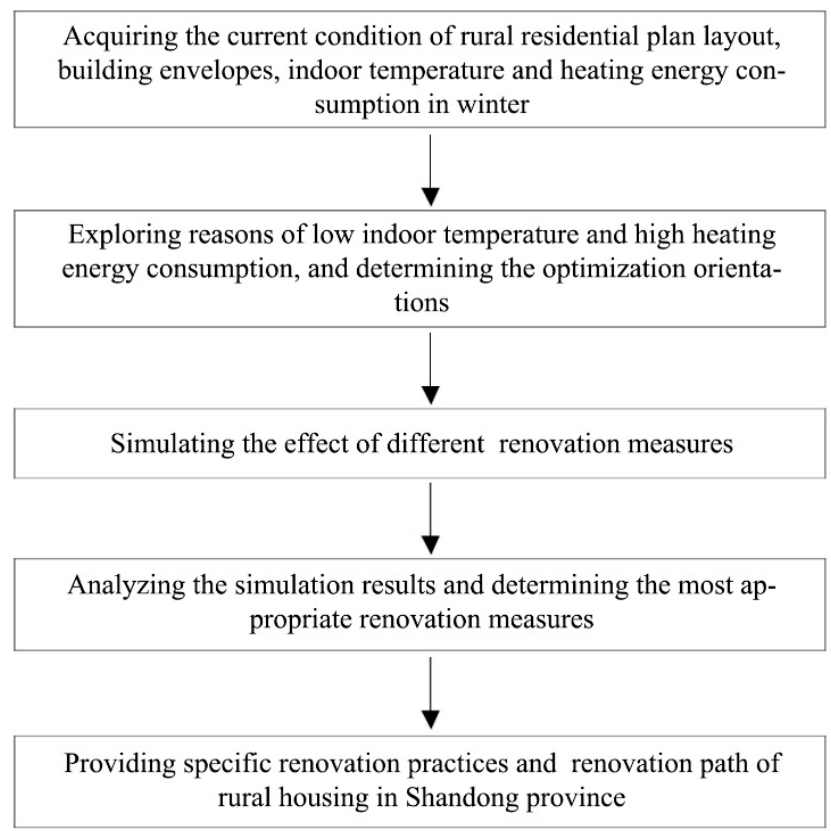

Figure 7. The flow for transforming a rural house.

\section{Simulation Method of Temperature in the Main Room and Heating Energy Consumption of Rural Houses}

With the limitation of economic conditions and ideological concepts, farmers pay special attention to the final effect of various transformation measures in the process of renovation for rural houses. In order to guide farmers to choose the most appropriate transformation measures, it is necessary to simulate the effect for the transformation measures, including renovation of the roof, exterior walls, doors, and windows, and building the sunspace. According to this field research, a typical rural house was selected from the surveyed rural houses as the simulation object, and the temperature of the main room in winter and the heating energy consumption of the rural house were considered as the simulating indicators, and DesignBuilder, which is widely recognized computer simulation software, was applied for simulation [30,34-36]. Specially, it firstly simulated the indoor temperature and energy consumption before the transformation, taken as the control group, and compared these simulating data with the measured data to verify the effectiveness of this model. Secondly, in accordance with the principle of a single variable, the indoor temperature and heating energy consumption of the rural house after the attached sunspace, renovation of roof, renovation of external walls, and renovation of doors and windows were simulated, respectively, which were taken as four experimental groups. Finally, the effect of the four measures applied at the same time was simulated. After completing the simulation, the results of the control group and the experimental group were compared and analyzed, and the best renovation measures were selected.

\subsection{Simulation Method before the Renovation}

Rural House 2, as shown in Figure 8, which was measured for indoor temperature, was selected as the simulation object. The courtyard size is $18.9 \times 17.7 \mathrm{~m}$, and it faces south with a floor area of $155 \mathrm{~m}^{2}$. It is a single-story building with a height of $3.6 \mathrm{~m}$, as shown in Figure 9. Based on the above 
basic information, the architectural analysis model was built up through DesignBuilder, as shown in Figure 10.
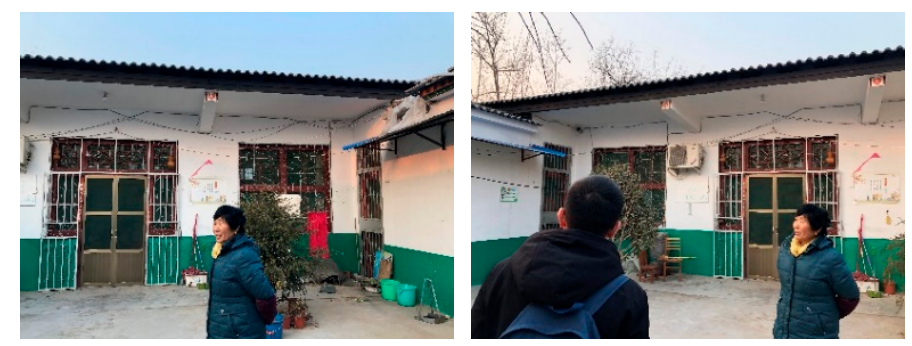

Figure 8. Appearance of Rural House 2.
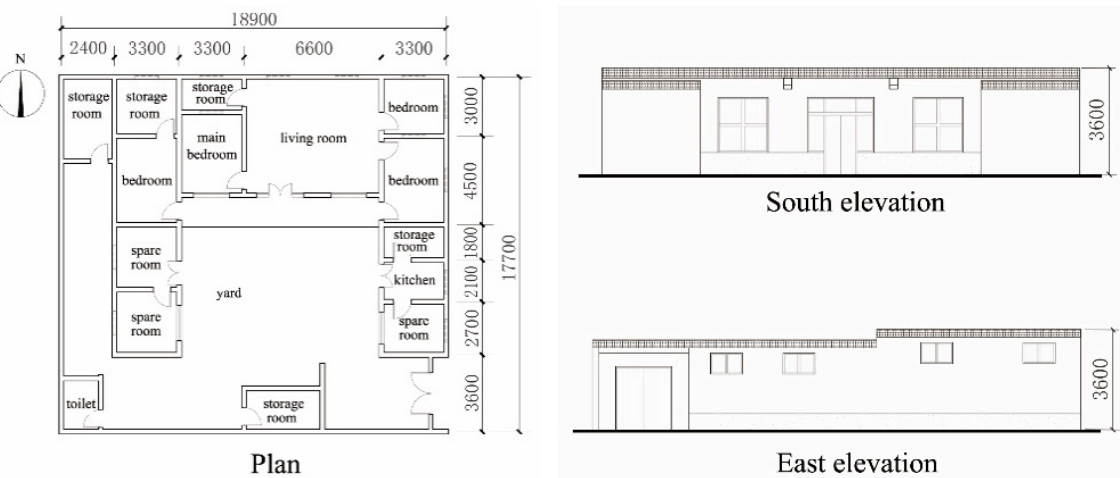

Figure 9. Plan and elevation of Rural House 2.

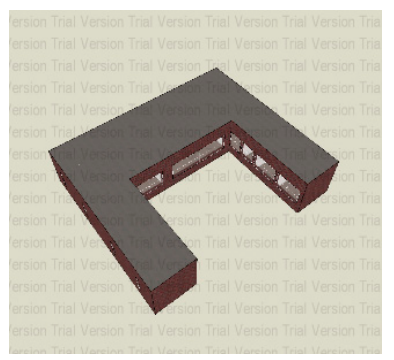

Figure 10. Architectural analysis model.

In terms of basic parameter settings, relevant parameters were set up according to the existing research results and the Chinese National Design Standard.

(1) Meteorological parameters. The research adopts the typical meteorological data of Jining city from the Chinese Standard Weather Data (CSWD) provided by the DesignBuilder software [37].

(2) Envelope parameters. The external wall of the typical rural house is a clay brick wall $240 \mathrm{~mm}$ thick. The roof is a $100 \mathrm{~mm}$ thick reinforced concrete roof, and there is no heat preservation layer, as shown in Table 2. For doors and windows, the door of the rural house is made from wood or aluminum, and the window is single glass with a wood frame or aluminum alloy frame [31,35].

(3) Heat source parameters in buildings. Through the study of the questionnaire survey for households, the indoor heat sources that have a significant impact on building energy consumption mainly include the personnel, and home appliance and lighting facilities in the master bedroom and living room. According to the research results, the heat output of indoor heat sources is about $5 \mathrm{~W} / \mathrm{m}^{2}[26]$.

(4) Heating design parameters. According to the questionnaire survey of households, the heating of rooms in a typical rural house includes the living room and four bedrooms, with a total heating 
area of $89 \mathrm{~m}^{2}$, as shown in Figure 11. The heating equipment used in the rural house is a coal stove with an energy efficiency ratio of 0.7. In accordance with the Chinese National Design Standard, the indoor ventilation rate when simulating is taken as 0.5 times $/ \mathrm{h}$, and the indoor heating temperature is taken as $14{ }^{\circ} \mathrm{C}$ [29].

Table 2. Building envelope information of Rural House 2.

\begin{tabular}{lcl}
\hline Envelope & Heat Transfer Coefficient $\left(\mathbf{W} / \mathbf{m}^{2} \cdot \mathbf{K}\right)$ & Structural Map \\
$\begin{array}{c}\text { External } \\
\text { walls }\end{array}$ & 2.07 & \\
Roof & 4.04
\end{tabular}

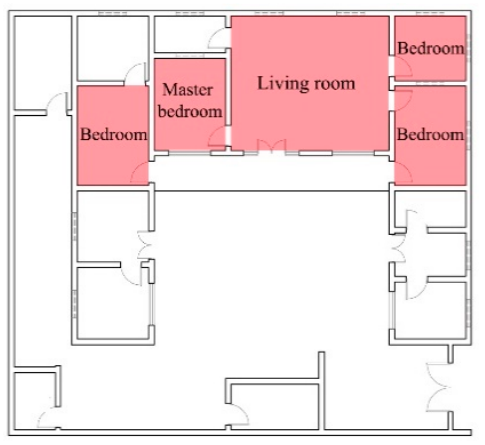

Figure 11. Rooms heated in Rural House 2.

After establishing the model and setting the parameters, the indoor temperature in the main room and the heating energy consumption of the building without renovation could be simulated. First of all, according to the research results, which show that the main room used in winter is the master bedroom, we principally used DesignBuilder to simulate the indoor temperature in the master bedroom without heating, with its specific date being consistent with the date of temperature measurement for four consecutive days including the day of Greater Cold (18 January-21 January). Then, we can compare the data between the simulation and measurement to verify the effectiveness of the analysis model [38]. Secondly, the annual cumulative heating energy consumption was calculated when the temperature in the heating room of the rural house was $14{ }^{\circ} \mathrm{C}$ and the indoor ventilation time was 0.5 times/h [29]. Therefore, we can credibly realize the indoor temperature of the main room and the heating energy consumption of the building before renovation.

\subsection{Simulation Method after the Renovation}

In order to obtain the specific effect of the renovated measures, DesignBuilder was used to simulate the temperature in the master bedroom and the heating energy consumption of the building under conditions of an attached sunspace, renovation of roof, renovation of external walls, and renovation of doors and windows, respectively. Then, the effect of the four measures applied at the same time 
was simulated. Since the limit value of the heat-transfer coefficient of the rural residential building envelope is stipulated by the Chinese National Design Standard, it was significant to ensure that the heat-transfer coefficient of each part after transformation in the rural house could reach the limit value, as shown in Table 3.

Table 3. Limit value of the heat-transfer coefficient for the rural building envelope in colder regions [29].

\begin{tabular}{|c|c|c|c|c|c|c|}
\hline & \multirow{2}{*}{ External Wall } & \multirow{2}{*}{ Roof } & \multicolumn{2}{|c|}{ External Window } & \multirow{2}{*}{ External Door } & \multirow{2}{*}{ Sunspace } \\
\hline & & & South & Others Orientation & & \\
\hline Limit value $\left(\mathrm{W} / \mathrm{m}^{2} \cdot \mathrm{K}\right)$ & 0.65 & 0.50 & 2.8 & 2.5 & 2.5 & 4.7 \\
\hline
\end{tabular}

The method of simulating the renovated effect of the measures is as follows:

(1) When the sunspace was added, the outdoor porch of Rural House 2 was closed with aluminum alloy insulating glass to form the sunspace. The heat-transfer coefficient of aluminum alloy insulating glass was set as the limit value of $4.7 \mathrm{~W} / \mathrm{m}^{2} \cdot \mathrm{K}$ [29], and other parameters remained the same as before the renovation.

(2) When the roof was transformed, the new waterproof layer, $50 \mathrm{~mm}$ thick extruded polystyrene board, and the new covering layer were successively laid on the roof of Rural House 2. After calculation, the heat-transfer coefficient of the reconstructed roof was about $0.50 \mathrm{~W} / \mathrm{m}^{2} \cdot \mathrm{K}$, which meets the limit value specified in the standard [29]. The heat-transfer coefficient of the roof was set as $0.50 \mathrm{~W} / \mathrm{m}^{2} \cdot \mathrm{K}$ in the model, and other parameters remained the same as before the renovation.

(3) When the external walls were transformed, the outer surface of the wall was sprayed with $25 \mathrm{~mm}$ thick rigid polyurethane foam, and then cement mortar and the new covering layer were laid successively. After calculation, the heat-transfer coefficient of the reconstructed exterior wall was about $0.65 \mathrm{~W} / \mathrm{m}^{2} \cdot \mathrm{K}$, which meets the limit value specified in the standard [29]. The heat-transfer coefficient of the exterior wall was set as $0.65 \mathrm{~W} / \mathrm{m}^{2} \cdot \mathrm{K}$ in the model, and other parameters remained the same as before the renovation.

(4) When the doors and windows were transformed, the south-facing exterior windows were replaced by the plastic steel insulating glass casement windows with a heat-transfer coefficient of $2.8 \mathrm{~W} / \mathrm{m}^{2} \cdot \mathrm{K}$. The other exterior windows were replaced by the plastic steel insulating glass casement windows with a heat-transfer coefficient of $2.5 \mathrm{~W} / \mathrm{m}^{2} \cdot \mathrm{K}$. The exterior door was replaced by the plastic steel casement door with a heat-transfer coefficient of $2.5 \mathrm{~W} / \mathrm{m}^{2} \mathrm{~K}$, which meets the limit value specified in the standard [29]. Other parameters remained the same as before the renovation.

(5) When all the parts were transformed, the above renovation measures were applied to Rural House 2 at the same time, including the attached sunspace, renovation of roof, renovation of external walls, and renovation of doors and windows, and the corresponding heat-transfer coefficients were set in the model. Other parameters remained the same as before the renovation.

After parameter setting, the above five conditions were simulated respectively. Firstly, the indoor temperature of the master bedroom in the rural house was simulated under the five different conditions without heating for four consecutive days, including the day of Greater Cold (18 January-21 January). Secondly, the annual cumulative heating energy consumption was simulated under the above five conditions when the indoor temperature in the rural house was $14{ }^{\circ} \mathrm{C}$ and the indoor ventilation time was 0.5 times/h [29]. Therefore, the indoor temperature of the main room and the heating energy consumption of the building was easily obtained after the renovation of the rural house, and the effect of renovation measures were informed by comparison with the relevant data obtained before the renovation. 


\section{Results and Discussion}

\subsection{Simulation Results of Temperature in the Main Room and Heating Energy Consumption of Rural Houses}

\subsubsection{Simulation Results before the Renovation and Model Validation}

Figure 12 shows the simulated temperature of the master bedroom in the rural house before the renovation; it can be analyzed from the graph that the lowest outdoor temperature during the process of simulation was about $-6.4^{\circ} \mathrm{C}$, which occurred at 4:00 a.m. on the third day. Meanwhile, the temperature in the master bedroom was about $1.3^{\circ} \mathrm{C}$, and then it descended to its lowest point of $0.5{ }^{\circ} \mathrm{C}$ after about $2.5 \mathrm{~h}$. The highest outdoor temperature was about $6.2{ }^{\circ} \mathrm{C}$, which occurred at around 3:00 p.m. on the fourth day. At this time, the temperature in the master bedroom was about $5.6^{\circ} \mathrm{C}$, and then it rose to its highest point of $6.4^{\circ} \mathrm{C}$ after $4 \mathrm{~h}$. The average temperature in the master bedroom was $3.6^{\circ} \mathrm{C}$, which was only 3.8 degrees higher than the outdoor average temperature of $-0.2^{\circ} \mathrm{C}$. The conclusions were drawn that the indoor temperature of the rural house kept a lower level before the renovation.

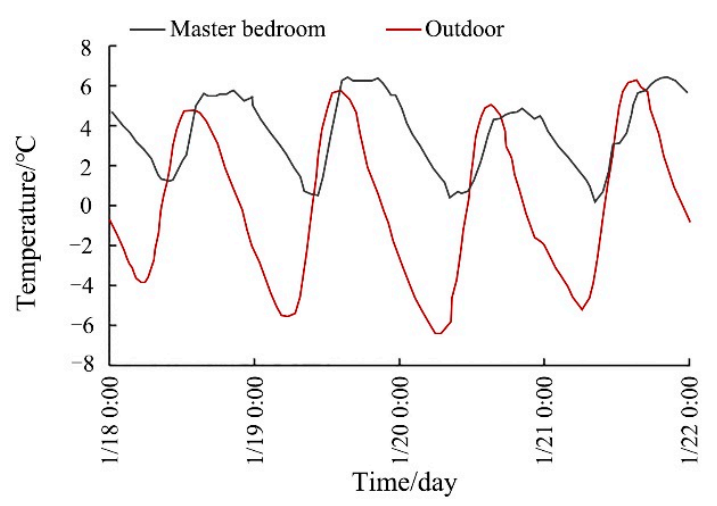

Figure 12. The simulated temperature before the renovation.

Comparing Figure 5 with Figure 12, we can find that the simulating temperature curve is consistent with the overall trend of the measured temperature curve. In comparison with the actual measured temperature data, the simulation results show that, according to the value of delta temperature $(\Delta T)$, as shown in Table 4, the simulating minimum temperature in the master bedroom is lower than the measured minimum temperature by $0.3^{\circ} \mathrm{C}$, the simulating maximum temperature in the master bedroom is higher than the measured maximum temperature by $1^{\circ} \mathrm{C}$, and the simulating average temperature is higher than the measured average temperature by $0.8^{\circ} \mathrm{C}$. All of them have errors of about $1^{\circ} \mathrm{C}$. According to the analysis, the main reason for the error is that there are some differences between the Chinese Standard Weather Data (CSWD) in the simulating process and the actual weather data in the measurement process. According to the value of delta temperature $(\Delta \mathrm{T})$ as shown in Table 4, the minimum temperature of the weather data used for simulation is lower than the measured minimum outdoor temperature by $0.6{ }^{\circ} \mathrm{C}$. The maximum temperature of the weather data used for simulation is higher than the measured maximum outdoor temperature by $1.1{ }^{\circ} \mathrm{C}$ and the average temperature of the weather data used for simulation is higher than the measured average outdoor temperature by $0.5^{\circ} \mathrm{C}$. In addition, the measuring accuracy of the temperature recorder itself can also lead to error. The errors caused by the above two reasons are hard to avoid and can be accepted in practical engineering. Therefore, it is reasonable and feasible to use this model for subsequent simulation analysis. 
Table 4. Comparison of measured and simulated temperature data.

\begin{tabular}{ccccccc}
\hline & \multicolumn{2}{c}{ Minimum Temperature $\left({ }^{\circ} \mathrm{C}\right)$} & \multicolumn{2}{c}{ Maximum Temperature $\left({ }^{\circ} \mathrm{C}\right)$} & \multicolumn{2}{c}{ Average Temperature $\left({ }^{\circ} \mathrm{C}\right)$} \\
\cline { 2 - 7 } & Outdoor & Master Bedroom & Outdoor & Master Bedroom & Outdoor & Master Bedroom \\
\hline Measurement & -5.8 & 0.8 & 5.1 & 5.4 & -0.7 & 2.8 \\
Simulation & -6.4 & 0.5 & 6.2 & 6.4 & -0.2 & 3.6 \\
$\Delta \mathrm{T}$ & -0.6 & -0.3 & 1.1 & 1 & 0.5 & 0.8 \\
\hline
\end{tabular}

Note: $\Delta \mathrm{T}=\mathrm{T}$ (simulation) $-\mathrm{T}$ (measurement)

The annual cumulative heating energy consumption in the rural house before the renovation was $9864.5 \mathrm{~kW} \cdot \mathrm{h}$ through simulation, and the annual cumulative heating energy consumption per unit area was $110.8 \mathrm{~kW} \cdot \mathrm{h} / \mathrm{m}^{2}$, which would translate to the amounts of $1213 \mathrm{~kg}$ of standard coal [39]. According to the research, the proportion of heat transfer between local common clean coal and standard coal is 1:0.75, and the conversion of standard coal to common clean coal is about $1617 \mathrm{~kg}$. Considering the market price of local clean coal is 1500 yuan per ton, thus it is estimated that the annual heating expense is about 2426 yuan. By investigating the annual income of 573 farmer families, as shown in Figure 13, we can see that annual household income less than 20,000 yuan accounted for $89 \%$ of households. It is also obvious that the heating energy consumption of rural houses without renovation in winter is very high, and the expense for heating accounts for a large proportion of the total household income, which will also cause serious environmental pollution. Therefore, the appropriate technical measures for renovation should be taken.

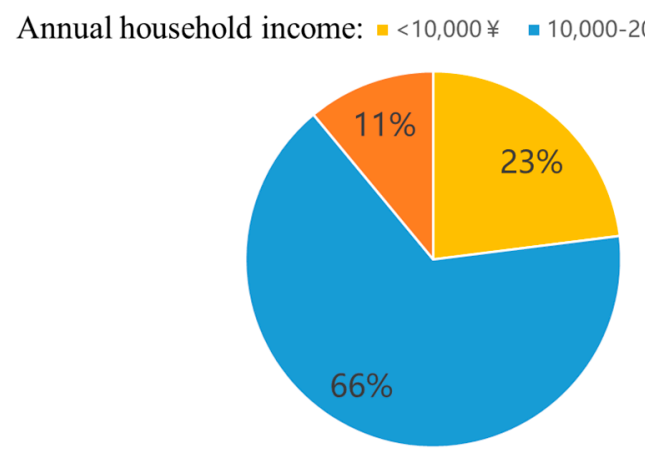

Figure 13. Distribution proportion of annual household income.

\subsubsection{Simulation Results after the Renovation}

(1) Building the attached sunspace. After the renovation, it can be calculated that the shape coefficient of Rural House 2 was reduced from 0.78 to 0.70 . Figure 14 shows the simulated temperature of the master bedroom in the rural house before and after the sunspace was added. In comparison with the temperature data shown in Table 5, it can be seen that the average temperature, highest temperature, and lowest temperature of the master bedroom after renovation would increase by $0.5,0.9$, and $0.6^{\circ} \mathrm{C}$, respectively, and the indoor temperature after the renovation gets much more stable. The simulation result also shows that the annual cumulative heating energy consumption of the rural house after adding the sunspace is $9037.2 \mathrm{~kW} \cdot \mathrm{h}$, and the annual cumulative heating energy consumption per unit area is $101.5 \mathrm{~kW} \cdot \mathrm{h} / \mathrm{m}^{2}$. Compared with that without renovation, the annual cumulative heating energy consumption that can be saved is $827.3 \mathrm{~kW} \cdot \mathrm{h}$ in the whole year after renovation, as shown in Figure 15, and the energy saving rate is $8.4 \%$. 


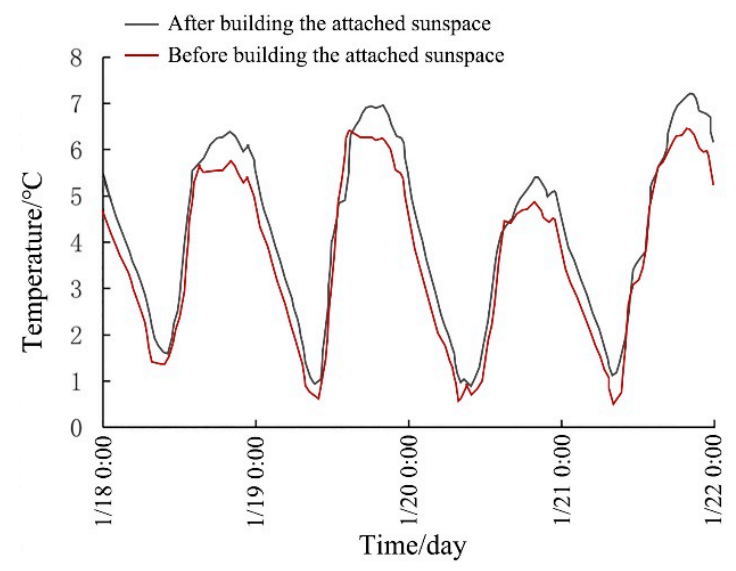

Figure 14. The simulated temperature of the master bedroom before and after building the sunspace.

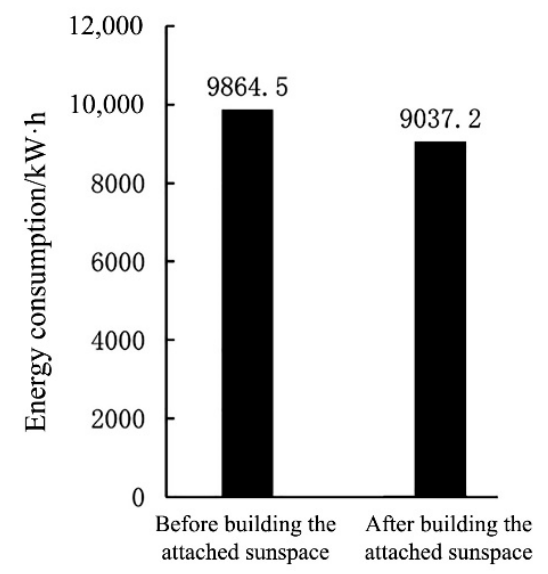

Figure 15. The annual cumulative heating energy consumption before and after building the sunspace.

Table 5. The data comparison of temperature and energy consumption before and after building the sunspace.

\begin{tabular}{cccc}
\hline & & $\begin{array}{c}\text { Before } \\
\text { Renovation }\end{array}$ & $\begin{array}{c}\text { After } \\
\text { Renovation }\end{array}$ \\
\hline \multirow{3}{*}{ Indoor Temperature } & Average Temperature $\left({ }^{\circ} \mathbf{C}\right)$ & 3.6 & 4.1 \\
& Maximum Temperature $\left({ }^{\circ} \mathbf{C}\right)$ & 6.4 & 7.3 \\
& Minimum Temperature $\left({ }^{\circ} \mathbf{C}\right)$ & 0.5 & 1.1 \\
& Standard Deviation $\left({ }^{\circ} \mathbf{C}\right)$ & 1.76 & 1.67 \\
\hline Heating Energy & Annual Cumulative Heating & 9864.5 & 9037.2 \\
Consumption & Energy Consumption $(\mathbf{k W} \cdot \mathbf{h})$ & & \\
& Annual Cumulative Heating & 110.8 & 101.5 \\
& Energy Consumption Per Unit & & \\
\hline & Area $\left(\mathbf{k W} \cdot \mathbf{h} / \mathbf{m}^{\mathbf{2}}\right)$ &
\end{tabular}

(2) Renovation of roof. Figure 16 shows the simulated temperature of the master bedroom in the rural house before and after the renovation of the roof. In comparison with the temperature data shown in Table 6, it indicates that the average temperature, highest temperature, and lowest temperature of the master bedroom after renovation increases by $2.1,1.3$, and $2.8^{\circ} \mathrm{C}$, respectively, and the indoor temperature after the renovation gets much more stable. The simulation result also shows that the annual cumulative heating energy consumption of the rural house after the renovation of the roof is $7131.6 \mathrm{~kW} \cdot \mathrm{h}$, and the annual cumulative heating energy consumption per unit area is $80.1 \mathrm{~kW} \cdot \mathrm{h} / \mathrm{m}^{2}$. Compared with that without renovation, the annual cumulative 
heating energy consumption that can be saved is $2732.9 \mathrm{~kW} \cdot \mathrm{h}$ in the whole year after renovation, as shown in Figure 17, and the energy saving rate is $27.7 \%$.

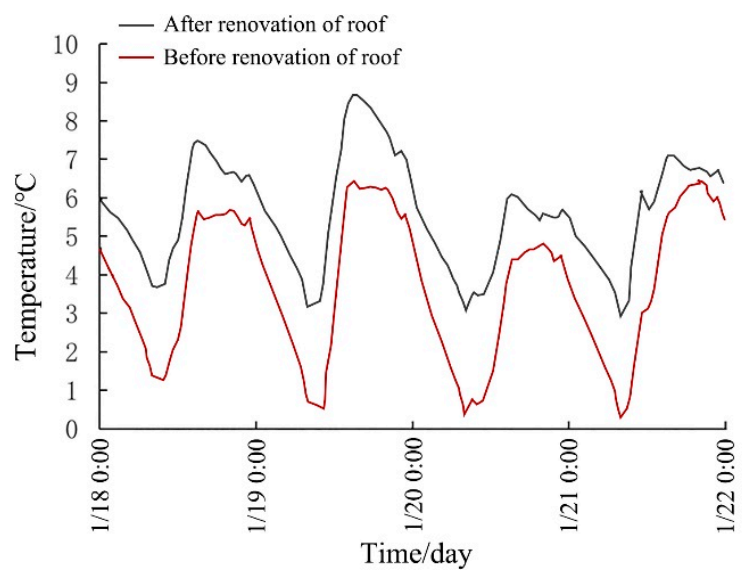

Figure 16. The simulated temperature of the master bedroom before and after renovation of the roof.

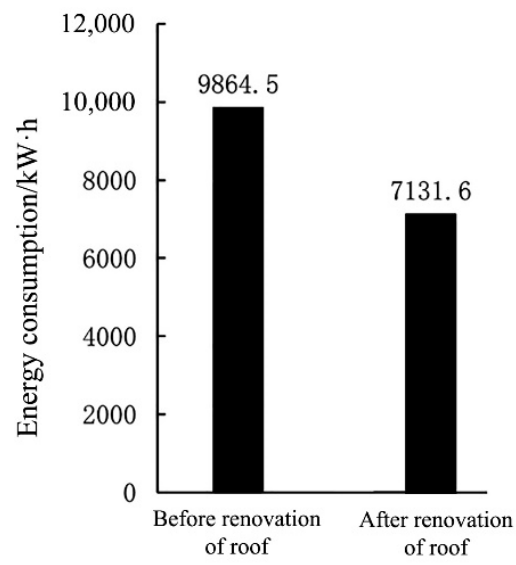

Figure 17. The annual cumulative heating energy consumption before and after renovation of the roof.

Table 6. The data comparison of temperature and energy consumption before and after renovation of the roof.

\begin{tabular}{|c|c|c|c|}
\hline & & $\begin{array}{c}\text { Before } \\
\text { Renovation }\end{array}$ & $\begin{array}{c}\text { After } \\
\text { Renovation }\end{array}$ \\
\hline \multirow{4}{*}{ Indoor Temperature } & Average Temperature $\left({ }^{\circ} \mathrm{C}\right)$ & 3.6 & 5.7 \\
\hline & Maximum Temperature $\left({ }^{\circ} \mathrm{C}\right)$ & 6.4 & 8.7 \\
\hline & Minimum Temperature $\left({ }^{\circ} \mathrm{C}\right)$ & 0.5 & 3.3 \\
\hline & Standard Deviation $\left({ }^{\circ} \mathrm{C}\right)$ & 1.76 & 1.31 \\
\hline \multirow{3}{*}{$\begin{array}{l}\text { Heating Energy } \\
\text { Consumption }\end{array}$} & $\begin{array}{l}\text { Annual Cumulative Heating } \\
\text { Energy Consumption }(\mathrm{kW} \cdot \mathrm{h})\end{array}$ & 9864.5 & 7131.6 \\
\hline & $\begin{array}{l}\text { Energy Consumption }(\mathrm{kW} \cdot \mathrm{h}) \\
\text { Annual Cumulative Heating }\end{array}$ & & \\
\hline & $\begin{array}{c}\text { Energy Consumption Per Unit } \\
\text { Area }\left(\mathrm{kW} \cdot \mathrm{h} / \mathrm{m}^{2}\right)\end{array}$ & 110.8 & 80.1 \\
\hline
\end{tabular}

(3) Renovation of exterior walls. Figure 18 shows the simulated temperature of the master bedroom in the rural house before and after the renovation of exterior walls. By comparing the temperature data shown in Table 7, the average temperature, highest temperature, and lowest temperature of the master bedroom after the renovation increases by 1,1 , and $1.1^{\circ} \mathrm{C}$, respectively, and the indoor temperature after the renovation gets much more stable. The simulation result also demonstrates 
that the annual cumulative heating energy consumption of the rural house after the renovation of exterior walls is $8272.2 \mathrm{~kW} \cdot \mathrm{h}$, and the annual cumulative heating energy consumption per unit area is $92.9 \mathrm{~kW} \cdot \mathrm{h} / \mathrm{m}^{2}$. Compared with that without renovation, the annual cumulative heating energy consumption that can be saved is $1592.3 \mathrm{~kW} \cdot \mathrm{h}$ in the whole year after renovation, as shown in Figure 19, and the energy saving rate is $16.1 \%$.

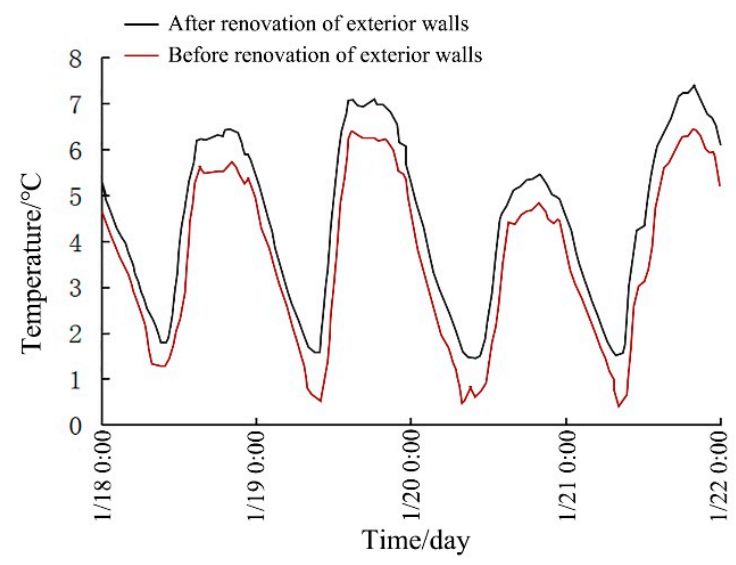

Figure 18. The simulated temperature of the master bedroom before and after renovation of exterior walls.

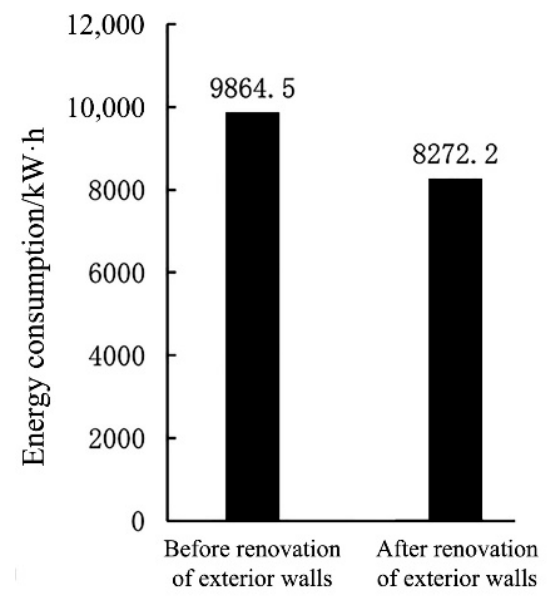

Figure 19. The annual cumulative heating energy consumption before and after renovation of exterior walls.

Table 7. The data of temperature and energy consumption before and after renovation of exterior walls.

\begin{tabular}{cccc}
\hline & & $\begin{array}{c}\text { Before } \\
\text { Renovation }\end{array}$ & $\begin{array}{c}\text { After } \\
\text { Renovation }\end{array}$ \\
\hline \multirow{3}{*}{ Indoor Temperature } & Average Temperature $\left({ }^{\circ} \mathbf{C}\right)$ & 3.6 & 4.6 \\
& Maximum Temperature $\left({ }^{\circ} \mathbf{C}\right)$ & 6.4 & 7.4 \\
& Minimum Temperature $\left({ }^{\circ} \mathbf{C}\right)$ & 0.5 & 1.6 \\
& Standard Deviation $\left({ }^{\circ} \mathbf{C}\right)$ & 1.76 & 1.55 \\
\hline \multirow{2}{*}{$\begin{array}{c}\text { Annual Cumulative Heating } \\
\text { Consumption }\end{array}$} & Energy Consumption $(\mathbf{k W} \cdot \mathbf{h})$ & 9864.5 & 8272.2 \\
& Annual Cumulative Heating & & \\
& Energy Consumption Per Unit & 110.8 & 92.9 \\
\hline & Area $\left(\mathbf{k W} \cdot \mathbf{h} / \mathbf{m}^{2}\right)$ & \\
\hline
\end{tabular}


(4) Renovation of doors and windows. Figure 20 shows the simulated temperature of the master bedroom in the rural house before and after the renovation of doors and windows. By comparing the temperature data shown in Table 8, the average temperature, highest temperature, and lowest temperature of the master bedroom after the renovation increases by $0.7,0.8$, and $0.9{ }^{\circ} \mathrm{C}$, respectively, and the indoor temperature after the renovation gets much more stable. The simulation result also exhibits that the annual cumulative heating energy consumption of the rural house after the renovation of doors and windows is $8627.2 \mathrm{~kW} \cdot \mathrm{h}$, and the annual cumulative heating energy consumption per unit area is $96.9 \mathrm{~kW} \cdot \mathrm{h} / \mathrm{m}^{2}$. Compared with that without renovation, the annual cumulative heating energy consumption that can be saved is $1237.3 \mathrm{~kW} \cdot \mathrm{h}$ in the whole year after renovation, as shown in Figure 21, and the energy saving rate is $12.5 \%$.

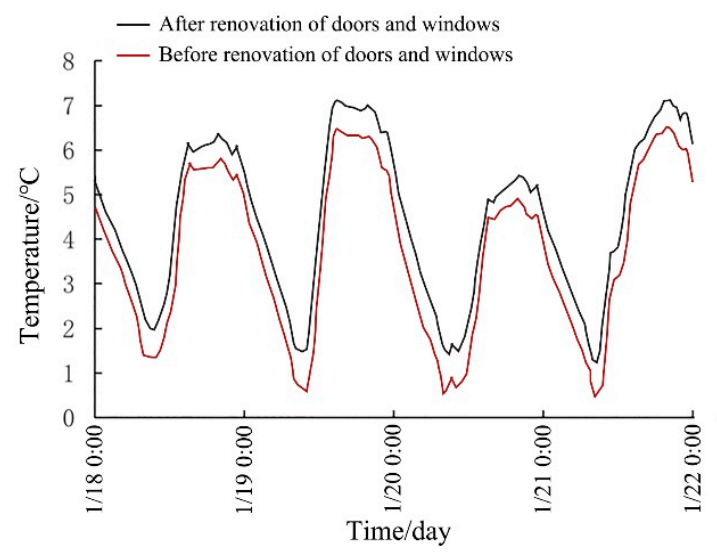

Figure 20. The simulated temperature of the master bedroom before and after renovation of doors and windows.

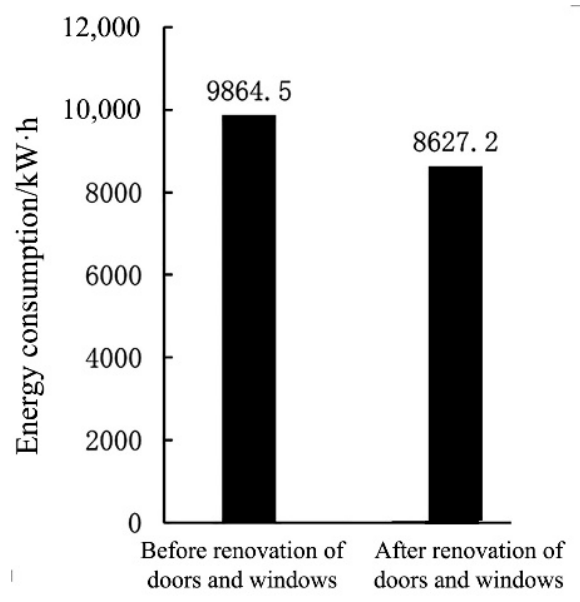

Figure 21. The annual cumulative heating energy consumption before and after renovation of doors and windows. 
Table 8. The data of temperature and energy consumption before and after renovation of doors and windows.

\begin{tabular}{cccc}
\hline & & $\begin{array}{c}\text { Before } \\
\text { Renovation }\end{array}$ & $\begin{array}{c}\text { After } \\
\text { Renovation }\end{array}$ \\
\hline \multirow{3}{*}{ Indoor Temperature } & Average Temperature $\left({ }^{\circ} \mathbf{C}\right)$ & 3.6 & 4.3 \\
& Maximum Temperature $\left({ }^{\circ} \mathbf{C}\right)$ & 6.4 & 7.2 \\
& Minimum Temperature $\left({ }^{\circ} \mathbf{C}\right)$ & 0.5 & 1.4 \\
& Standard Deviation $\left({ }^{\circ} \mathbf{C}\right)$ & 1.76 & 1.61 \\
\hline Heating Energy & Annual Cumulative Heating & 9864.5 & 8627.2 \\
Consumption & Energy Consumption $(\mathbf{k W} \cdot \mathbf{h})$ & & \\
& Annual Cumulative Heating & 110.8 & 96.9 \\
& Energy Consumption Per Unit & & \\
\hline
\end{tabular}

(5) Renovation of all parts. Figure 22 shows the simulated temperature of the master bedroom in the rural house before and after the renovation of all parts. In comparison with the temperature data shown in Table 9, it indicates that the average temperature, highest temperature, and lowest temperature of the master bedroom after renovation increases by $6.2,5.4$, and $7.6^{\circ} \mathrm{C}$, respectively, and the indoor temperature after the renovation gets much more stable. The simulation result also shows that the annual cumulative heating energy consumption of the rural house after the renovation of all parts is $2870.3 \mathrm{~kW} \cdot \mathrm{h}$, and the annual cumulative heating energy consumption per unit area is $32.3 \mathrm{~kW} \cdot \mathrm{h} / \mathrm{m}^{2}$. Compared with that without renovation, the annual cumulative heating energy consumption that can be saved is $6994.2 \mathrm{~kW} \cdot \mathrm{h}$ in the whole year after renovation, as shown in Figure 23, and the energy saving rate is $70.9 \%$.

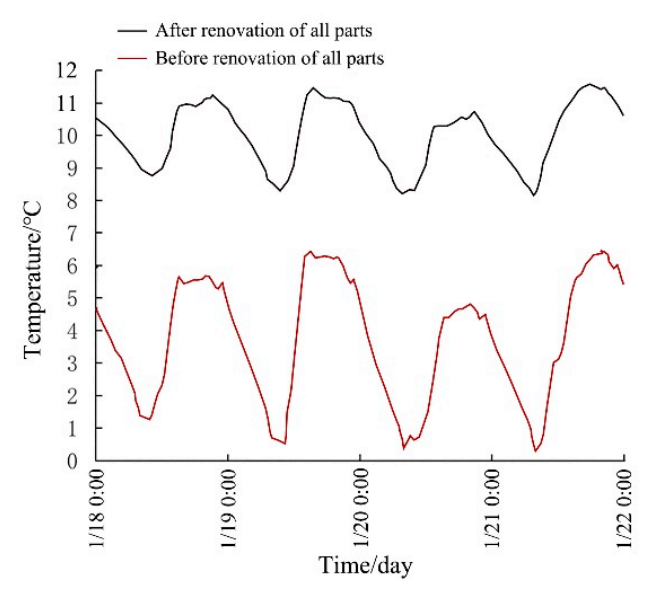

Figure 22. The simulated temperature of the master bedroom before and after renovation of all parts. 


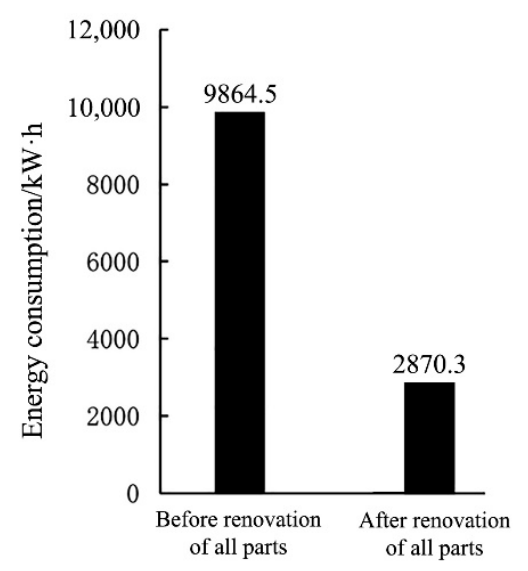

Figure 23. The annual cumulative heating energy consumption before and after renovation of all parts.

Table 9. The data comparison of temperature and energy consumption before and after renovation of all parts.

\begin{tabular}{cccc}
\hline & & $\begin{array}{c}\text { Before } \\
\text { Renovation }\end{array}$ & $\begin{array}{c}\text { After } \\
\text { Renovation }\end{array}$ \\
\hline \multirow{2}{*}{ Indoor Temperature } & Average Temperature $\left({ }^{\circ} \mathbf{C}\right)$ & 3.6 & 9.8 \\
& Maximum Temperature $\left({ }^{\circ} \mathbf{C}\right)$ & 6.4 & 11.8 \\
& Minimum Temperature $\left({ }^{\circ} \mathbf{C}\right)$ & 0.5 & 8.1 \\
& Standard Deviation $\left({ }^{\circ} \mathbf{C}\right)$ & 1.76 & 1.09 \\
\hline Heating Energy & Annual Cumulative Heating & 9864.5 & 2870.3 \\
Consumption & Energy Consumption $(\mathbf{k W} \cdot \mathbf{h})$ & & \\
& Annual Cumulative Heating & 110.8 & 32.3 \\
& Energy Consumption Per Unit & & \\
\hline & Area $\left(\mathbf{k W} \cdot \mathbf{h} / \mathbf{m}^{\mathbf{2}}\right)$ & \\
\hline
\end{tabular}

Based on the above simulation results, in terms of temperature, through comparing the increase in average temperature, highest temperature, and lowest temperature with different renovation measures in the master bedroom, as shown in Table 10, all renovation measures could improve the indoor temperature of the master bedroom in various degrees in winter, among which the best approach is renovation of all parts with the largest increase in temperature, followed by roof, exterior walls, doors and windows, and building the attached sunspace. Compared with the decrease of standard deviation $(\sigma)$ for the master bedroom's temperature after using different renovation measures, as shown in Table 10, the simulation indicated that the indoor temperature of the rural house after renovation of all parts had the best stability, followed by renovation of the roof, renovation of exterior walls, renovation of doors and windows, and building the attached sunspace. For energy consumption, when comparing the annual cumulative heating energy consumption of houses after implementing different renovation measures, as shown in Figure 24, it can be found that renovation of all parts was the most energy-saving, followed by the roof, external walls, doors and windows, and attached sunspace. The energy saving rates of each measure are $70.9 \%, 27.7 \%, 16.1 \%, 12.5 \%$, and $8.4 \%$, respectively. Therefore, for rural residential buildings, according to the simulation results of indoor temperature and heating energy consumption in winter, it could be known that the renovation of all parts can obtain the best effect, which is also the best measure, followed by the renovation of roof, exterior walls, doors and windows, and finally the attached sunspace. 
Table 10. Effects of different renovation measures on indoor temperature.

\begin{tabular}{cccccc}
\hline & $\begin{array}{c}\text { Building the } \\
\text { Attached } \\
\text { Sunspace }\end{array}$ & $\begin{array}{c}\text { Renovation of } \\
\text { Roof }\end{array}$ & $\begin{array}{c}\text { Renovation of } \\
\text { Exterior Walls }\end{array}$ & $\begin{array}{c}\text { Renovation of } \\
\text { Doors and } \\
\text { Windows }\end{array}$ & $\begin{array}{c}\text { Renovation of } \\
\text { All Parts }\end{array}$ \\
\hline $\boldsymbol{\Delta} \mathrm{T}$ (Average temperature) & 0.5 & 2.1 & 1 & 0.7 & 6.2 \\
$\Delta \mathrm{T}$ (Maximum temperature) & 0.9 & 1.3 & 1 & 0.8 & 5.4 \\
$\Delta \mathrm{T}$ (Minimum temperature) & 0.6 & 2.8 & 1.1 & 0.9 & 7.6 \\
$\Delta \boldsymbol{\sigma}$ & 0.09 & 0.45 & 0.21 & 0.15 & 0.67 \\
\hline
\end{tabular}

Note: $\Delta \mathrm{T}$ (Average temperature) $=\mathrm{T}$ (Average temperature after renovation) $-\mathrm{T}$ (Average temperature before renovation); $\Delta \mathrm{T}$ (Maximum temperature) $=\mathrm{T}$ (Maximum temperature after renovation) $-\mathrm{T}$ (Maximum temperature before renovation); $\Delta \mathrm{T}$ (Minimum temperature) $=\mathrm{T}$ (Minimum temperature after renovation) $-\mathrm{T}($ Minimum temperature before renovation); $\Delta \sigma=\sigma$ (Before renovation) $-\sigma$ (After renovation).

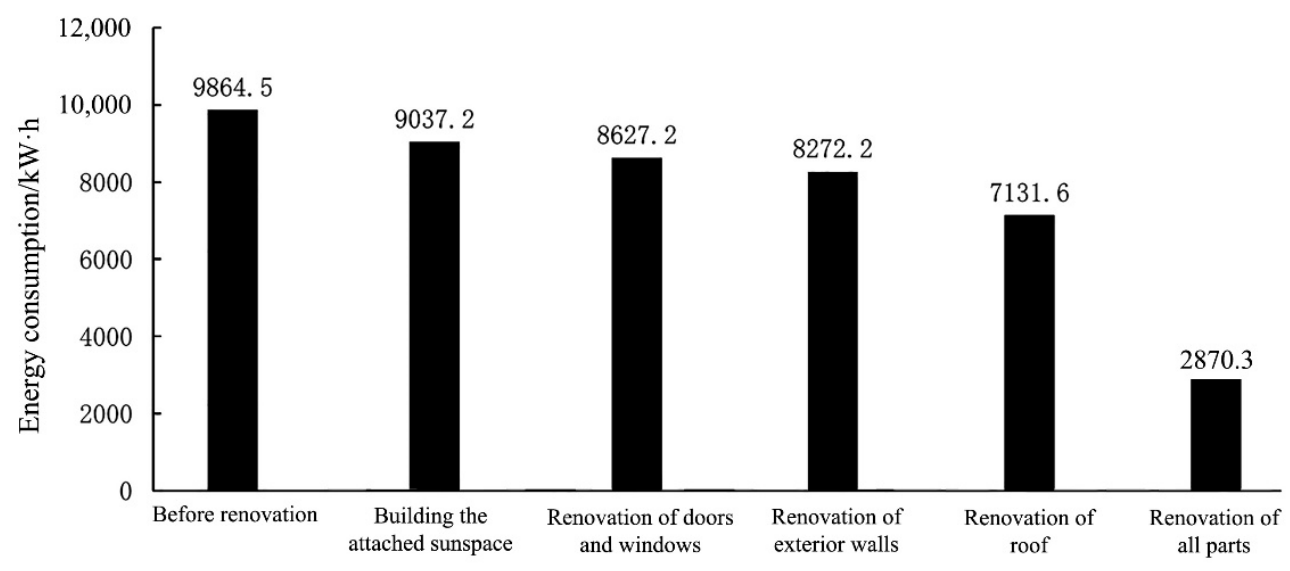

Figure 24. Effects of different renovation measures on heat energy consumption.

\subsection{Rural Residential Indoor Temperature after the Actual Renovation}

Rural House 2 has been practically renovated, including renovation of the roof, renovation of external walls, renovation of external windows, and building the attached sunspace, as shown in Figure 25. In addition, the indoor temperature without heating was measured from 18 January to 21 January in 2020. Figure 26 shows the temperature curve. The average temperature in the master bedroom is $9.8^{\circ} \mathrm{C}$, the highest temperature is $11.5^{\circ} \mathrm{C}$, and the lowest temperature is $8.3^{\circ} \mathrm{C}$. The average temperature in the living room is $9.4^{\circ} \mathrm{C}$, the highest temperature is $11.0^{\circ} \mathrm{C}$, and the lowest temperature is $7.9^{\circ} \mathrm{C}$. Comparing the temperature before and after the transformation, as shown in Figures 5 and 26, on the premise that the outdoor temperature basically remains the same, it indicates that the average temperature, highest temperature, and lowest temperature of the master bedroom after renovation increases by $7.0,6.1$, and $7.5^{\circ} \mathrm{C}$, respectively. The average temperature, highest temperature, and lowest temperature of the living room after renovation increases by $6.9,5.9$, and $7.3^{\circ} \mathrm{C}$, respectively. The indoor temperature increases greatly, and the indoor temperature after the renovation gets much more stable. Therefore, the renovation measures are reasonable and effective.
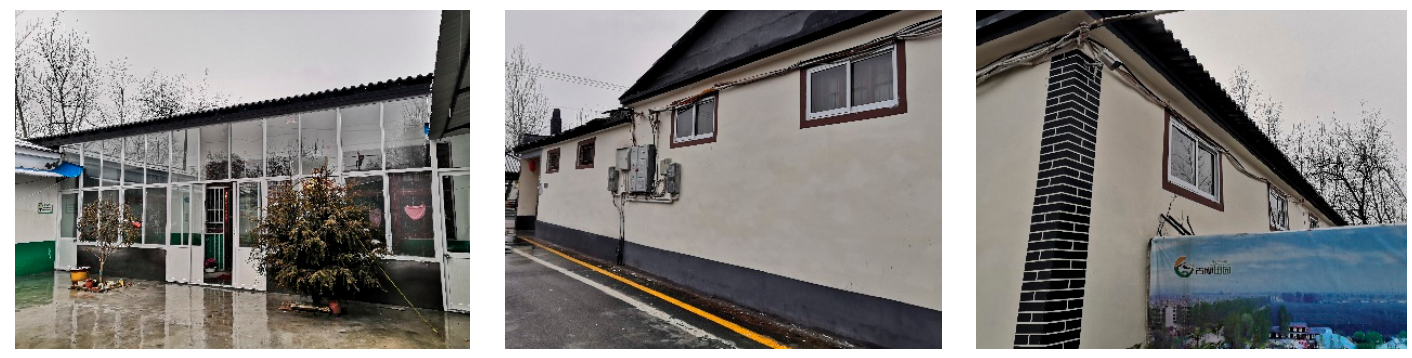

Figure 25. The transformed Rural House 2. 


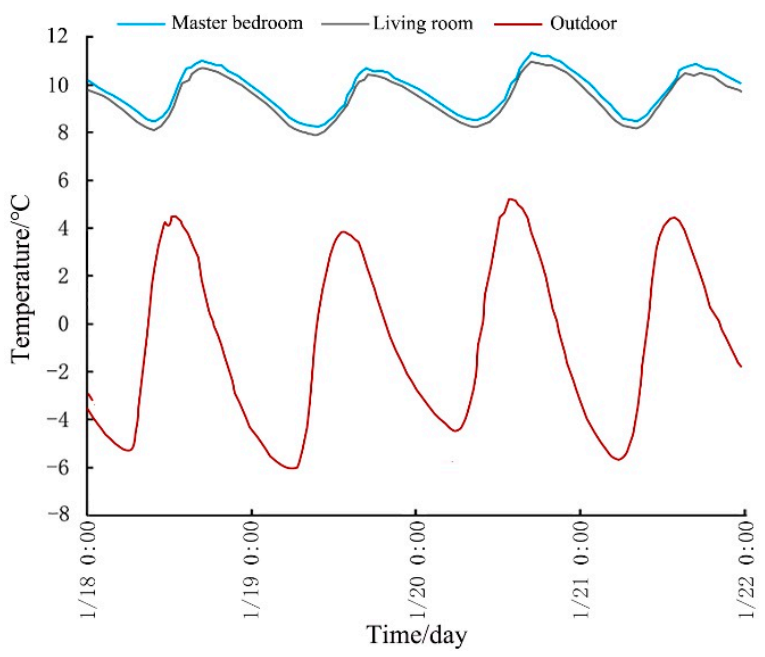

Figure 26. The temperature of Rural House 2 after the renovation.

\subsection{Specific Renovation Practices of Rural Houses}

For the rural house that has been transformed into "Beautiful Countryside", it is essential to avoid damaging the existing appearance of the rural house during the transforming process of energy saving and comfort. Hence, specific renovation practices should be proposed according to different situations, and the contents are as follows:

(1) Building the attached sunspace. The sunspace should not damage the appearance of the rural house. For the rural house with an outdoor porch on the south side, the solid wall can be directly built in the porch, and then the aluminum alloy frame and insulating glass or plastic frame and insulating glass can be applied to close the front porch and form a sunspace, as shown in Figure 27. To keep the overall appearance of the rural house with beauty and harmony, it would be allowable to paint the window frames in the sunspace, still generally keeping consistency between the color of the sunspace and the rural house.

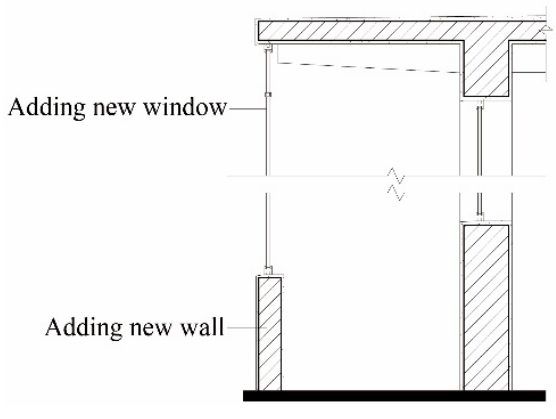

Figure 27. Attached sunspace.

(2) Renovation of roof. For the rural house with a flat roof, the thermal insulation layer can be laid on the roof, which has the advantages of a good thermal insulation effect, simple construction, and no damage to the existing appearance of the rural house. The specific renovation practice is to lay the waterproof layer on the roof, then lay the extruded polystyrene board, and lay the covering layer, as shown in Figure 28. For the rural house with a pitched roof, the insulation layer cannot lay on the roof surface without avoiding the original form of the roof being damaged. It is recommended to add an indoor thermal insulation ceiling. The specific renovation practice is to install a light steel keel under the floor, and then lay the thermal insulation composite panel composed of phenolic foam board and a covering layer, as shown in Figure 29. Due to China's 
rural houses commonly being intermittently heated in the colder regions, building the indoor insulation ceiling can also increase the rate of temperature rise.

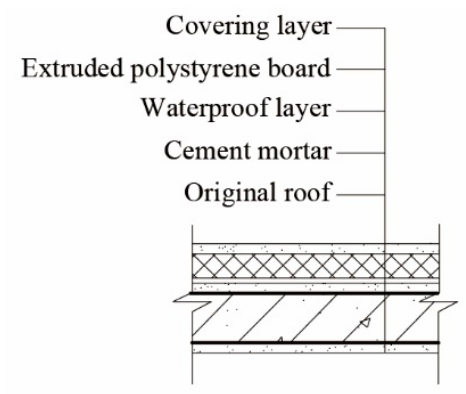

Figure 28. Outdoor roof insulation.

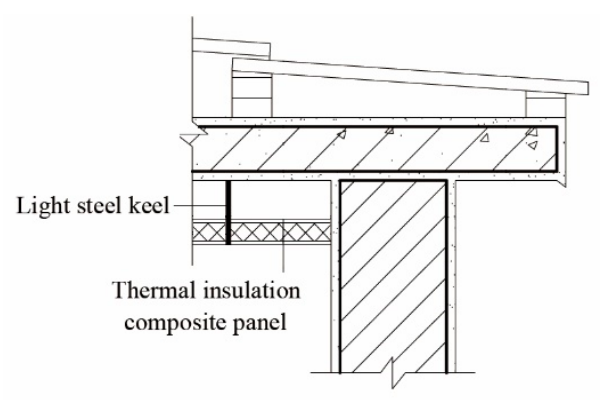

Figure 29. Indoor insulation ceiling.

(3) Renovation of exterior walls. For brick rural houses with the exterior wall repainted, and stone houses and adobe houses with regional characteristics, it is common that the exterior walls are quite beautiful. Therefore, in order to avoid damage to the appearance of the exterior walls, the insulation layer can be laid on the internal surface of the wall, which should not be too thick to reduce the occupied area of the houses. The specific renovation practice is to lay the polyurethane insulation board on the inner surface of the wall, and then lay the cement mortar and the covering layer, as shown in Figure 30. For brick rural houses without the exterior wall repainted, it is relatively shabby in general, and the thermal insulation layer can be laid on the external surface of the wall. This method cannot only improve the thermal insulation performance of walls, but also can improve the appearance of walls. The specific renovation practice is to spray rigid polyurethane foam on the outer surface of the wall, and then lay the cement mortar and the covering layer, as shown in Figure 31.

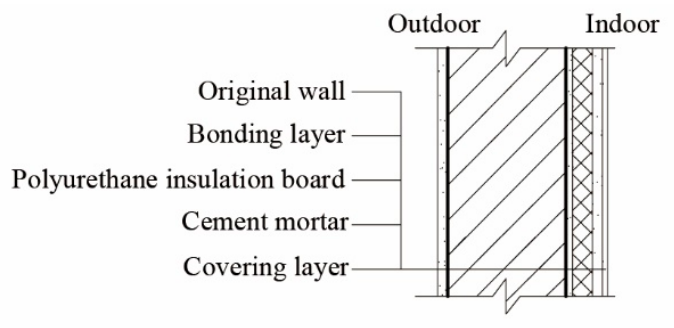

Figure 30. Internal thermal insulation. 


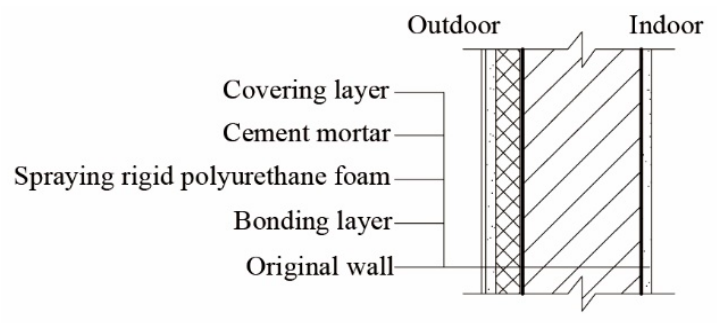

Figure 31. External thermal insulation.

(4) Renovation of doors and windows. Doors and windows should be directly replaced, allowing newness, a better thermal insulation effect, and air tightness, which should not damage the appearance of rural houses. Therefore, the old exterior windows can be directly changed with casement windows with plastic steel frames and insulating glass or broken bridge aluminum alloy frames and insulating glass, as shown in Figure 32. Besides, the exterior doors can be replaced with swing doors with plastic steel. Furthermore, the original doors and windows can also be retained, and new doors and windows can be added directly on the inside or outside of the original doors and windows, thereby forming double-skin doors and windows, as shown in Figure 33.

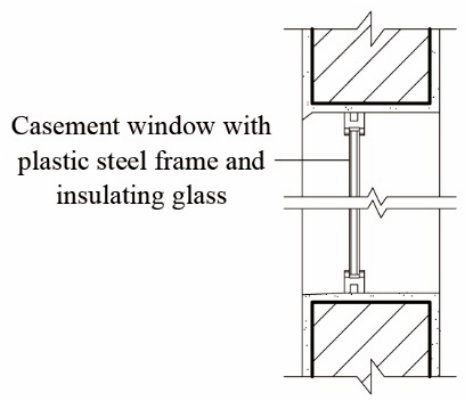

Figure 32. Replacing with a new window.

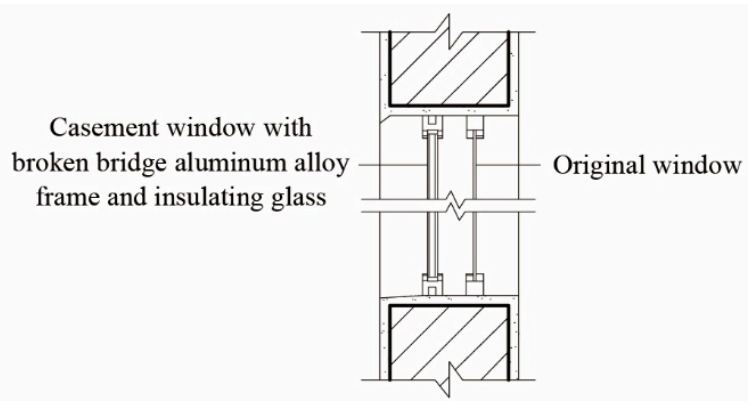

Figure 33. Adding a new window.

\subsection{The Renovation Path of Rural Houses}

The majority of rural areas in China are characterized by different levels of development and economy. However, overall, farmer's economic income in rural areas is much lower than that of urban residents. Therefore, more consideration should be given to actual economic conditions of farmers in the process of rural house renovation. However, the designer should not one-sidedly focus on pursuing lower costs and ignoring the renovating effect. The reason is that it will reduce the comfort for the rural residents and have a long-range implication on the residents' health if the indoor temperature of the renovated rural house is lower. Additionally, the heating expenses cannot be saved by the farmers, and it will be unfriendly to our environment due to the large amounts of greenhouse gas emissions in 
the heating process if the heating energy consumption in the renovated rural house is still at a high level. Consequently, the renovation path of rural houses should match the economic level of farmers. The specific path is as follows:

For rural areas with better economic conditions in Shandong Province, overall renovation of rural houses should be carried out, including renovation of the roof, renovation of exterior walls, renovation of doors and windows, and building the attached sunspace. According to the results of the simulation, the energy saving rate of the overall renovation can reach about $70.9 \%$, which can meet the requirements of the design standard in Shandong Province; to be more specific, when the main rooms, such as master bedrooms or living rooms, reach conditions of comfort, energy efficiency can be increased by over 30\% [40]. Through the simulation and temperature measurement, it can be seen that after the overall renovation, the indoor temperature of the rural house can be increased by $6-7^{\circ} \mathrm{C}$ without heating, which has a good renovation effect.

For the rural areas with weak economic conditions in Shandong Province, it should follow the principle of "gradual improvement", namely, one measure with a relatively good effect should be given priority, and other measures should be taken gradually if economic conditions permit. Based on the above simulating analysis, it can be seen that the roof should be transformed first, followed by the renovation of exterior walls, the renovation of doors and windows, and finally the attached sunspace.

\section{Conclusions}

At present, there are some issues for rural houses in colder areas, such as the lower indoor temperature and higher energy consumption, and these are some of the bigger constraints to rural economic development and environmental protection. The comfort improvement of rural residents and energy saving is to improve farmers' living environment, solve the growing energy consumption in rural houses, and realize the target of new socialistic rural construction. Through this paper, the following conclusions can be drawn:

(1) The rural houses renovated by "Beautiful Countryside" have been greatly improved in terms of architectural appearance. However, due to the lack of renovation of the physical properties of the building envelope, the heat-transfer coefficient of the envelope is relatively high, resulting in the appearance of a series of corresponding problems, such as low indoor temperature and high energy consumption. Therefore, reasonable measures should be taken for renovation.

(2) The main technique to improve the indoor temperature and reduce energy consumption of the rural house is to promote the thermal insulation performance of the building envelope. Since rural houses have an aesthetic change from the "Beautiful Countryside" transformation, the negative influence or damage to the current appearance of rural houses should be avoided when improving the thermal insulation performance of the building envelope. The specific transformation measures are to renovate the roof, exterior walls, doors and windows of the rural house, and build the attached sunspace.

(3) When transforming the rural house, it is not enough to carry out heat preservation transformation to the partial building envelope of the rural house, because the heat will be lost through other parts, and the rural house should be completely transformed, including renovation of the roof, exterior walls, doors and windows, and building the sunspace. China's rural areas have different levels of economic development, so they cannot follow a unified standard in the process of renovation. For the areas with better economic conditions or a developed economy, overall renovation of rural houses should be carried out, including renovation of the roof, exterior walls, doors and windows, and building the sunspace. According to the simulation and temperature measurement, it can be seen that after the overall renovation, the energy saving rate of the rural house can reach more than $70 \%$, and the indoor temperature can be increased by $6-7^{\circ} \mathrm{C}$ without heating. For the areas with weak economic conditions, the method of "gradual improvement" can be adopted. Specifically, one measure with a relatively good effect should be given priority, and other measures can be taken gradually if economic conditions permit. Through the simulating 
analysis of indoor temperature and energy consumption in the rural house before and after implementing different renovation measures, it can be seen that the roof should be transformed first, followed by the exterior walls, doors and windows, and finally the attached sunspace.

Author Contributions: Conceptualization, Y.C. and N.S.; methodology, Y.C. and N.S.; software, N.S.; validation, N.S.; formal analysis, N.S. and H.C.; investigation, N.S. and H.C.; resources, N.S. and S.L.; data curation, N.S.; writing —original draft preparation, N.S.; writing-review and editing, Y.C. and N.S.; visualization, N.S. and S.L.; supervision, Y.C. and H.C.; project administration, Y.C. and N.S.; funding acquisition, Y.C. All authors have read and agreed to the published version of the manuscript.

Funding: This research was funded by the Key Research and Development Program of Rural Housing Construction in Shandong Province, China, grant number FW170705.

Conflicts of Interest: The authors declare no conflict of interest.

\section{References}

1. National Bureau of Statistics of China. China Statistical Yearbook 2019; China Statistics Press: Beijing, China, 2019.

2. Shan, M.; Wang, P.S.; Li, J.R.; Yue, G.X.; Yang, X.D. Energy and environment in Chinese rural buildings: Situations, challenges, and intervention strategies. Build. Environ. 2015, 91, 271-282. [CrossRef]

3. Evans, M.; Yu, S.; Song, B.; Deng, Q.Q.; Liu, J.; Delgado, A. Building energy efficiency in rural China. Energy Policy 2014, 64, 243-251. [CrossRef]

4. Ma, M.D.; Cai, W.G.; Wu, Y. China Act on the Energy Efficiency of Civil Buildings (2008): A decade review. Sci. Total Environ. 2019, 651, 42-60. [CrossRef] [PubMed]

5. Jiang, L.; Chen, X.P.; Xue, B. Features, Driving Forces and Transition of the Household Energy Consumption in China: A Review. Sustainability 2019, 11, 1186. [CrossRef]

6. Han, Y.; Yu, H.; Sun, C. Simulation-Based Multiobjective Optimization of Timber-Glass Residential Buildings in Severe Cold Regions. Sustainability 2017, 9, 2353. [CrossRef]

7. Yuan, P.L.; Lin, D.M.; Wang, Z.S. Coal consumption prediction model of space heating with feature selection for rural residences in severe cold area in China. Sustain. Cities Soc. 2019, 50, 101643. [CrossRef]

8. Building Energy Conservation Research Center of Tsinghua University. China Building Energy Efficiency Annual Development Report in 2018; China Building Industry Press: Beijing, China, 2018.

9. China Association of Building Energy Efficiency. Research Report on Building Energy Consumption in China. Available online: https://mp.weixin.qq.com/s/I63nbYoEww7oSf-gT7dneA (accessed on 5 January 2020).

10. Zhu, Y.Y.; Fan, X.N.; Sang, G.C.; Zhao, Q.; Cui, X.L. Study on indoor thermal environment of rural dwellings in Northwest China in winter. J. Phys. Conf. Ser. 2019, 1176, 042024. [CrossRef]

11. Cao, B.; Zhu, Y.X.; Li, M.; Ouyang, Q. Individual and district heating: A comparison of residential heating modes with an analysis of adaptive thermal comfort. Energy Build. 2014, 78, 17-24. [CrossRef]

12. Liu, Y.F.; Li, T.; Song, C.; Wang, D.J.; Liu, J.P. Field study of different thermal requirements based on the indoor activities patterns of rural residents in winter in Northwest China. Sci. Technol. Built Environ. 2018, 24, 867-877. [CrossRef]

13. Yang, L.; Yan, H.Y.; Lam, J.C. Thermal comfort and building energy consumption implications-A review. Appl. Energy 2014, 115, 164-173. [CrossRef]

14. Liu, D.R.; Ren, Z.G.; Wei, S.; Song, Z.; Li, P.P.; Chen, X. Investigations on the Winter Thermal Environment of Bedrooms in Zhongxiang: A Case Study in Rural Areas in Hot Summer and Cold Winter Region of China. Sustainability 2019, 11, 4720. [CrossRef]

15. Kong, X.Z.; Lu, Y.X. Five Models for Constructing Ecologically Livable Beautiful Countryside and Countermeasures. Econ. Rev. J. 2019, 1, 19-28.

16. He, B.J.; Yang, L.; Ye, M.; Mou, B.; Zhou, Y.A. Overview of rural building energy efficiency in China. Energy Policy 2014, 69, 385-396. [CrossRef]

17. Qi, F.; Cui, F.J.; Lv, W.L.; Zhang, T.L.; Musonda, B.M. Regional similarity of shape coefficient of rural residences-Taking Hangzhou rural region as a case. Build. Simul. 2019, 12, 597-604. [CrossRef]

18. Zhao, T.Y.; Liu, Y.S. Study on Practical Approach for Green Building Action of Towns and Villages in Severe Cold Region. Build. Sci. 2015, 31, 1-6. 
19. Ling, W.; Jin, H. Vernacular. Livable. Green: Research on Improvement of Human Settlements Environment of Rural Residential Building in North Base on Survey and Field Test. Build. Sci. 2018, 34, 147-155.

20. Yan, H.Y.; Li, D.Y.; Li, T. Research on Indoor Thermal Environment of Residential Building in Jiaozuo in Winter. Build. Sci. 2016, 32, 21-28.

21. Liu, Y.N.; Hou, L.S. Research on the Suitable Technology Paths of Clean Heating in Mountainous Countryside of Beijing. Build. Sci. 2019, 35, 128-134.

22. Shao, N.N.; Zhang, J.L.; Ma, L.D. Analysis on indoor thermal environment and optimization on design parameters of rural residence. J. Build. Eng. 2017, 12, 229-238. [CrossRef]

23. Lu, S.L.; Tang, X.L.; Ji, L.R.; Tu, D.X. Research on Energy-Saving Optimization for the Performance Parameters of Rural-Building Shape and Envelope by TRNSYS-GenOpt in Hot Summer and Cold Winter Zone of China. Sustainability 2017, 9, 294. [CrossRef]

24. Lu, S.L.; Wang, R.; Zheng, S.Q. Passive Optimization Design Based on Particle Swarm Optimization in Rural Buildings of the Hot Summer and Warm Winter Zone of China. Sustainability 2017, 9, 2288. [CrossRef]

25. Hu, S.; Yan, D.; Cui, Y. Influence of Building Space Form on the Energy Consumption of Residential Buildings. Build. Sci. 2015, 31, 118-123.

26. Zhang, G.L.; Zhang, Q.; Wang, F.; Wang, Q.; Liang, R. Study on Influencing Factors of Energy Consumption in Traditional Rural Dwellings of Kangding Prefecture Based on DesignBuilder. Build. Sci. 2019, 35, 108-115.

27. Chen, J.F.; Du, T.T. Low Energy Consumption Design Strategy Study on the Northeast Rural Residence in the Several Cold Region. Archit. J. 2016, 14, 22-28.

28. Shao, Y.; Zhou, X.H.; Meng, Y.P.; Wang, P. Optimized Design of Low-Energy Exterior Walls of Rural Residences in Cold Regions. Archit. J. 2016, 5, 77-80.

29. Ministry of Housing and Urban-Rural Development of the People's Republic of China. Design Standard for Energy Efficiency of Rural Residential Building; China Building Industry Press: Beijing, China, 2013.

30. Gou, S.Q.; Li, Z.R.; Zhao, Q.; Nik, V.M.; Scartezzini, J.L. Climate responsive strategies of traditional dwellings located in an ancient village in hot summer and cold winter region of China. Build. Environ. 2015, 86, 151-165. [CrossRef]

31. Shao, T.; Jin, H. The impact of rural house's orientation on heating energy consumption in severe cold regions of China. IOP C Ser. Earth Environ. 2019, 257, 012035. [CrossRef]

32. Shao, N.N.; Ma, L.D.; Zhang, J.L. Study on the rural residence heating temperature based on the residents behavior pattern in South Liaoning province. Energy Build. 2018, 174, 179-189. [CrossRef]

33. James, O.C. Architecture E Passive Design; Design Media Publishing Limited: New York, NY, USA, 2016.

34. Friess, W.A.; Rakhshan, K.; Hendawi, T.A.; Tajerzadeh, S. Wall insulation measures for residential villas in Dubai: A case study in energy efficiency. Energy Build. 2012, 44, 26-32. [CrossRef]

35. Li, K.; Zhao, T. The effect of envelope components on thermal performance of rural houses in Hubei, China. Indoor Built Environ. 2019, 28, 1272-1287. [CrossRef]

36. Aboelata, A.; Sodoudi, S. Evaluating urban vegetation scenarios to mitigate urban heat island and reduce buildings' energy in dense built-up areas in Cairo. Build. Environ. 2019, 166, 106407. [CrossRef]

37. Pitts, A.; Gao, Y.; Le, V.T. Opportunities to Improve Sustainable Environmental Design of Dwellings in Rural Southwest China. Sustainability 2019, 11, 5515. [CrossRef]

38. Deng, J.; Tian, Z.Y.; Fan, J.H.; Yang, M.; Furbo, S.; Wang, Z.F. Simulation and optimization study on a solar space heating system combined with a low temperature ASHP for single family rural residential houses in Beijing. Energy Build. 2016, 126, 2-13. [CrossRef]

39. National Bureau of Statistics of China. China Energy Statistical Yearbook 2018; China Statistics Press: Beijing, China, 2019.

40. Department of Housing and Urban-Rural Development of Shandong Province. Technical Guidelines for Energy Saving Renovation of Existing Residential Building Envelope in Shandong Province; China Building Materials Press: Beijing, China, 2018.

(C) 2020 by the authors. Licensee MDPI, Basel, Switzerland. This article is an open access article distributed under the terms and conditions of the Creative Commons Attribution (CC BY) license (http://creativecommons.org/licenses/by/4.0/). 